\title{
Multi-Scale Characean Experimental System: From Electrophysiology of Membrane Transporters to Cell-to-Cell Connectivity, Cytoplasmic Streaming and Auxin Metabolism
}

\author{
Mary J. Beilby* \\ School of Physics, The University of New South Wales, Sydney, NSW, Australia
}

The morphology of characean algae could be mistaken for a higher plant: stem-like axes with leaf-like branchlets anchored in the soil by root-like rhizoids. However, all of these structures are made up of giant multinucleate cells separated by multicellular nodal complexes. The excised internodal cells survive long enough for the nodes to give rise to new thallus. The size of the internodes and their thick cytoplasmic layer minimize

OPEN ACCESS

Edited by:

David Domozych,

Skidmore College, USA

Reviewed by:

Tomomichi Fujita,

Hokkaido University, Japan

Sven B. Gould,

Heinrich Heine University Düsseldorf,

Germany

${ }^{*}$ Correspondence:

Mary J. Beilby

m.j.beilby@unsw.edu.au

Specialty section:

This article was submitted to Plant Evolution and Development,

a section of the journal

Frontiers in Plant Science

Received: 13 April 2016

Accepted: 05 July 2016

Published: 25 July 2016

Citation:

Beillby MJ (2016) Multi-Scale

Characean Experimental System: From Electrophysiology of Membrane

Transporters to Cell-to-Cell

Connectivity, Cytoplasmic Streaming

and Auxin Metabolism.

Front. Plant Sci. 7:1052.

doi: 10.3389/fpls.2016.01052 impalement injury and allow specific micro-electrode placement. The cell structure can be manipulated by centrifugation, perfusion of cell contents or creation of cytoplasmic droplets, allowing access to both vacuolar and cytoplasmic compartments and both sides of the cell membranes. Thousands of electrical measurements on intact or altered cells and cytoplasmic droplets laid down basis to modern plant electrophysiology. Furthermore, the giant internodal cells and whole thalli facilitate research into many other plant properties. As nutrients have to be transported from rhizoids to growing parts of the thallus and hormonal signals need to pass from cell to cell, Characeae possess very fast cytoplasmic streaming. The mechanism was resolved in the characean model. Plasmodesmata between the internodal cells and nodal complexes facilitate transport of ions, nutrients and photosynthates across the nodes. The internal structure was found to be similar to those of higher plants. Recent experiments suggest a strong circadian influence on metabolic pathways producing indole-3-acetic acid (IAA) and serotonin/melatonin. The review will discuss the impact of the characean models arising from fragments of cells, single cells, cell-to-cell transport or whole thalli on understanding of plant evolution and physiology.

\footnotetext{
Keywords: Characeae, cell-to-cell transport, cytoplasmic droplets, cytoplasmic streaming, metabolic pathways, plasma membrane transporters, plasmodesmata, tonoplast transporters
}

\section{INTRODUCTION}

From all the charophytes, Characeae morphology appears most similar to embryophytes (land plants). The thallus consists of axial stem with leaf-like side branches and is anchored in the soil by root-like rhizoids. However, all these structures are made from large single cells with multiple nuclei, connected by nodal complexes consisting from small cells with single nuclei (Figure 1). 
A

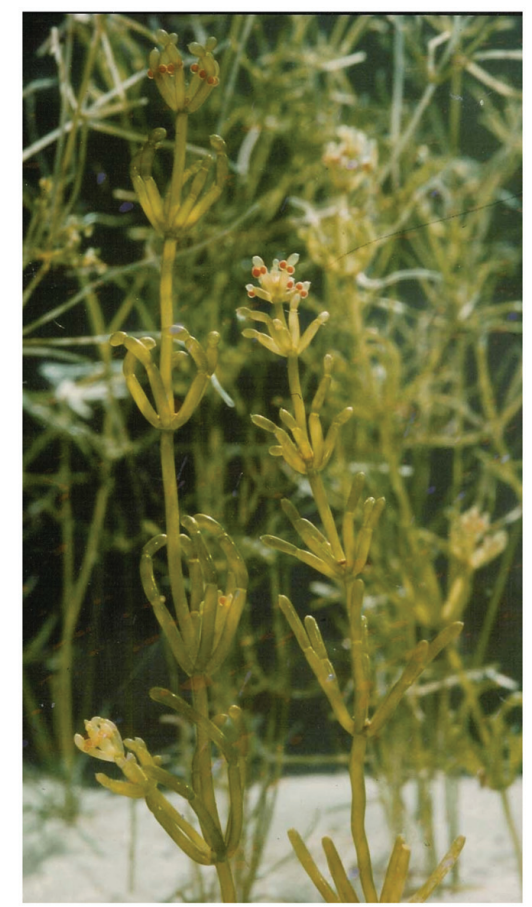

B

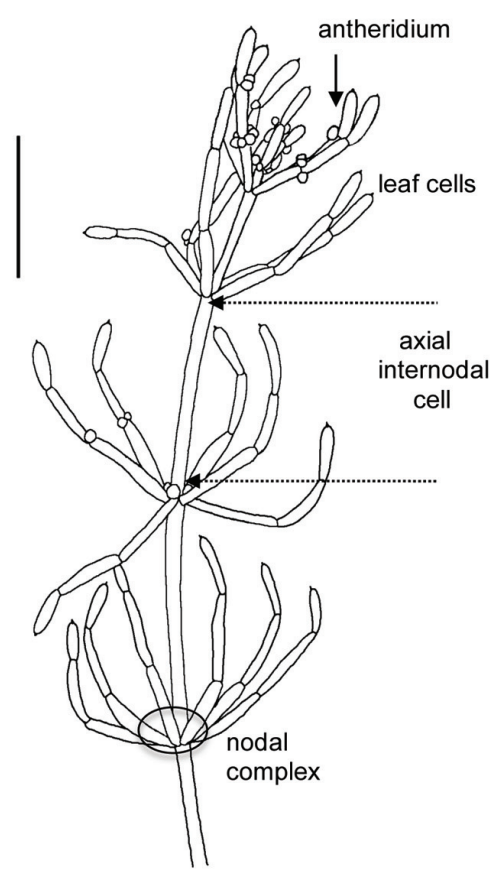

FIGURE 1 | General morphology of the characean plant. Chara australis is one of the most used characean experimental systems. (A) Plants are perennial and easily cultured in the lab setting for many years. (B) Male plant, identified by orange antheridia, with whorls of six branchelets. Multicellular nodes connect the axial internodes and the branchelets. The rhizoids (not shown) are also made up of large cells joined end to end. The scale bar is 10 mm. Part (B) is adapted from Beilby and Casanova (2013). For more details of Characeae morphology and variation between species see Beilby and Casanova (2013).

The axial internode cells grow up to diameter of $1 \mathrm{~mm}$ and up to half meter long in some species (see chapter 1 of Beilby and Casanova, 2013). New thalli regenerate from the nodal complexes.

Initially, Characeae seemed to be the closest streptophyte algal relatives to land plants (Karol et al., 2001), but recently Coleochaetophyceae or Zygnematophyceae moved into that position (Wodniok et al., 2011; Timme et al., 2012). Wickett et al. (2014) provide strong support for Zygnematophyceae to be the sister-group to land plants. This result is confirmed by plastid phylogenomics (Ruhfel et al., 2014) and plastid genome content (de Vries et al., 2016). Now that Chara braunii genome is in process of being sequenced and annotated and sequencing of the members from the other two classes is imminent, we can look forward to more complete solution to this puzzle.

The size of characean internodal cells makes it a good system for electrophysiology (for review see chapters 2 and 3 of Beilby and Casanova, 2013; Beilby, 2015). These cells fully recover after excision from the thallus and can be subjected to prolonged experiments ( $24 \mathrm{~h}$ and more) with multiple electrodes. For history of pioneering electrical and transport measurements on the characean plants see Walker (1955) and Hope and Walker (1975).

In this review, I will touch on electrophysiology, but mainly in context of exploring transporters at the tonoplast and plasma membrane often initially described in the Characeae. Some of these transporters contribute to supplying the plant with chloride, nitrogen, phosphorus and potassium - elements vital to all plants (carbon transport is covered in another review: Beilby and Bisson, 2012). The movement of ions and nutrients through the characean thallus depends strongly on cytoplasmic streaming. The characean cell size and morphology facilitated the identification of the streaming mechanism. Plasmodesmata are another important element of cell-to-cell transport with some basic experiments made possible by the characean cell size and organization. Another aspect of plant physiology that can be studied in Characeae is metabolic pathways. Beilby et al. (2015) found circadian changes in endogenous concentration of indole-3-acetic acid (IAA) in Chara australis, confirming that the entanglement of this important hormone with the circadian clock pre-dates the emergence of plants on land.

\section{ONE PLANT - MANY EXPERIMENTAL SYSTEMS}

The morphology of Characeae facilitates creation of experimental systems on many different levels:

(i) Cytoplasmic droplets that allow patch clamp investigation of tonoplast channels. 
(ii) Perfusion and permeabilization that create access to both sides of plasma membrane and tonoplast in single cell context.

(iii) Multi-compartmented cell holders that expose different parts of single cell to different media and tracer substances.

(iv) Two or more tandem cells to measure cell-to-cell transport electrically and by tracers.

(v) Whole thallus assays, where the results are dominated by contents of the large axial and leaf internodes with similar biochemistry and structure.

\section{Perfusion, Permeabilized Plasma Membrane and Cytoplasmic Droplets: Tonoplast Transporters}

The cylindrical symmetry of the large internodal cells allows perfusion of the vacuolar contents. The cell is put in a threewell holder (Figure 2A) with perfusion medium in pools $\mathrm{A}$ and $\mathrm{C}$ and the cell ends are cut. An inclination of the cell holder or higher fluid level in one of the wells creates pressure gradient to replace the vacuolar sap by artificial medium (Figure 2B, for the detailed technique description see Tazawa, 1964; Beilby,

A

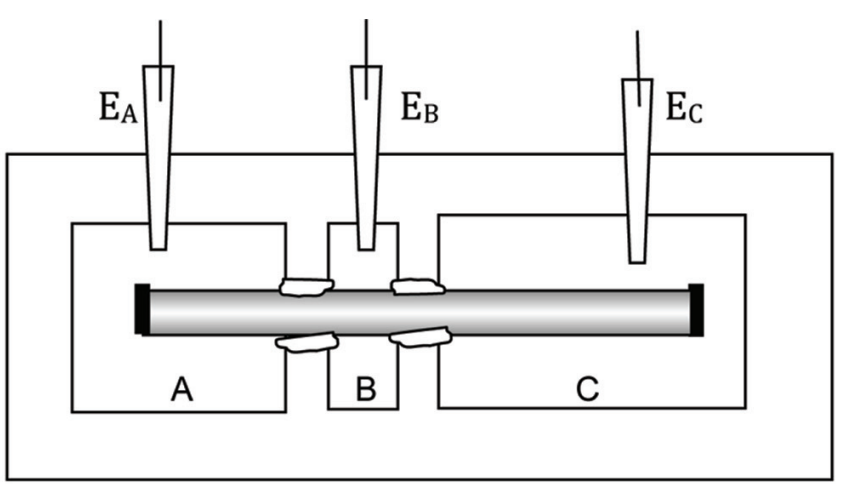

B

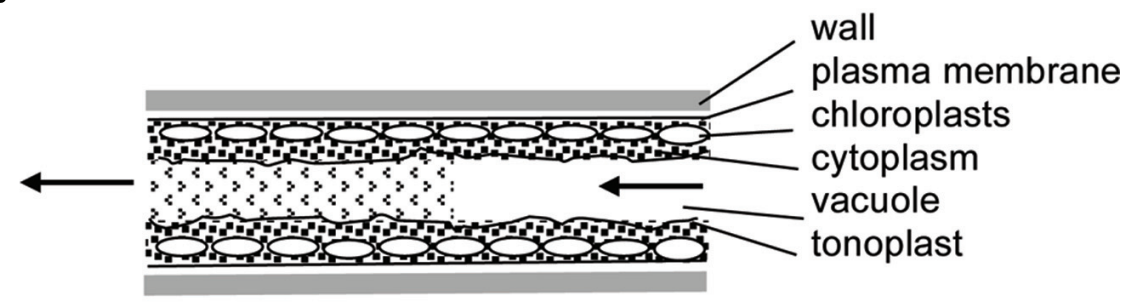

C

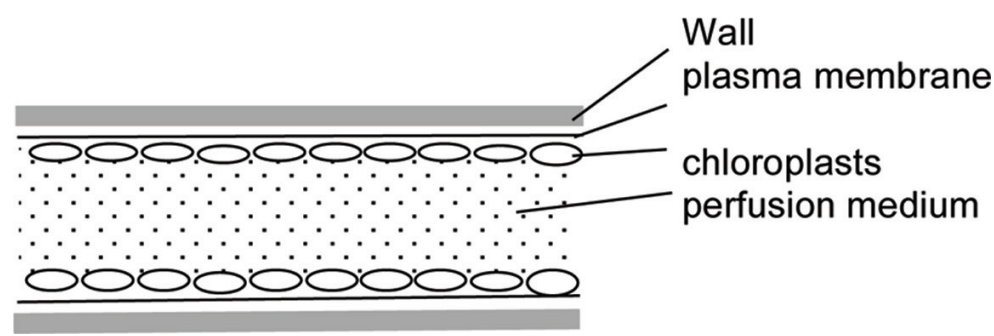

FIGURE 2 | Experimental techniques. (A) Multi-compartment Perspex or Lucite cell holder is employed in many types of experiments. The axial internodes grow to up to $30 \mathrm{~cm}$, so more than three compartments can be introduced. The compartments are electrically insulated by applying silicon grease or Vaseline to the cells at each partition. In the three-compartment holder one compartment (e.g., B) can be filled with 50 - $100 \mathrm{mM} \mathrm{KCl}$, reducing the membrane PD to zero due to activation of high conductance $\mathrm{K}^{+}$channels (Beilby, 1985). The other compartments are filled with artificial pond water (APW) with osmolarity adjusted, so no water transport occurs between parts of the cell. The reading of electrodes $E_{A}-E_{B}$ approximates the trans-membrane PD. In this technique no electrode insertion is necessary - very useful for wound and mechanical stress investigations. To perform vacuolar or cytoplasmic perfusion, chambers A and C are filled with perfusion medium, B with external medium. The nodes at the ends of the cell (shown as black rectangles) are cut and pressure gradient introduced, so that the vacuolar medium is replaced by artificial medium. In this case electrode $E_{A}$ or $E_{C}$ become the "internal" electrodes, while electrode $E_{B}$ is the external electrode. The rate of perfusion and/or the perfusion medium composition determines if the cell retains tonoplast (B) or not (C). For more details see text. 


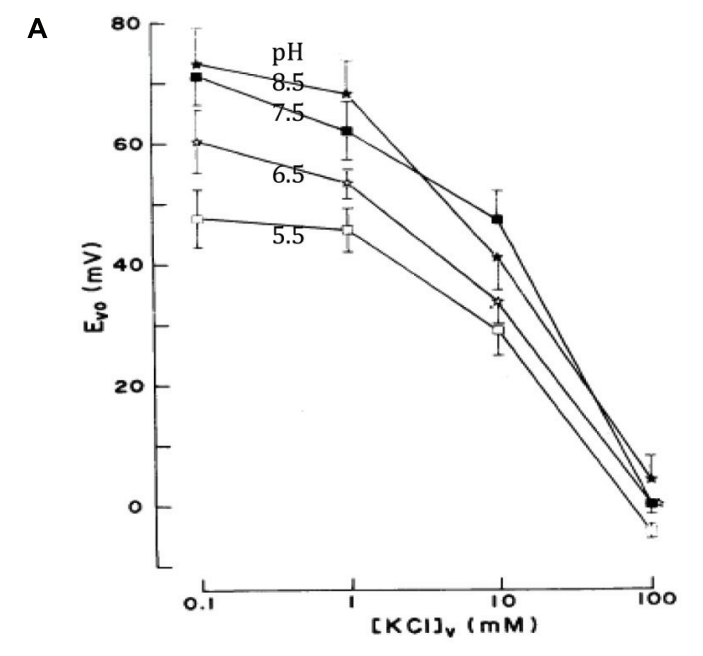

B

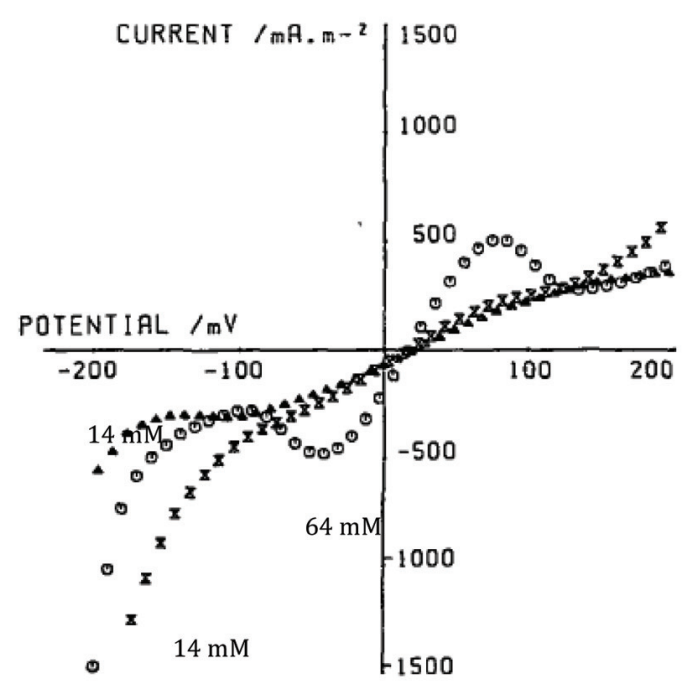

C



FIGURE 3 | Tonoplast transporters. (A) Vacuolar PD ( $\left.E_{\mathrm{vo}}\right)$ as function of vacuolar perfusion medium $\mathrm{K}^{+}$concentration and $\mathrm{pH}$ (for details see Moriyasu et al., 1984b). (B) I/N characteristics of the tonoplast with natural vacuolar sap and permeabilized plasma membrane with high (64 mM, empty circles) or low (14 mM, triangles before high concentration exposure and crossed triangles after) cytoplasmic $\mathrm{Cl}^{-}$(Tester et al., 1987). (C) Time-averaged IN characteristics of single tonoplast $\mathrm{K}^{+}$channels from several patches from cytoplasmic droplets (Laver and Walker, 1987).

1989). The perfusion can be repeated with different media, but cells are not turgid and survive only some hours. For electrical contact, the "internal electrode" is submerged into one of the outer compartments, and the "external electrode" into the middle compartment. The cell ends can be ligated with thread to ensure longer survival, but the composition of the medium changes with time.

\section{Tonoplast Proton Pumps}

Moriyasu et al. (1984a) demonstrated that the vacuolar $\mathrm{pH}$ is regulated close to 5 , regardless of $\mathrm{pH}$ of the external medium. The perfused cells responded slowly to $\mathrm{pH}$ increase with inhibition by Dicyclohexylcarbodiimide (DCCD), while $\mathrm{pH}$ decrease was corrected quickly without inhibition, suggesting presence of ATP powered proton pump as well as $\mathrm{H}^{+} / \mathrm{OH}^{-}$channels in the tonoplast. To resolve tonoplast electrical characteristics Moriyasu et al. (1984b) increased the conductance of the plasma membrane by including $110 \mathrm{mM} \mathrm{KCl}$ in the external medium, opening large conductance $\mathrm{K}^{+}$channels. The potential difference (PD) across the tonoplast then dominated the combined PD across both membranes. Changing $\mathrm{K}^{+}$concentration in the perfusion medium revealed passive tonoplast $\mathrm{PD}$ due to potassium (Figure 3A). At low internal $\mathrm{K}^{+}(0.1 \mathrm{mM})$ the $\mathrm{PD}$ generated by the proton pump, while regulating vacuolar $\mathrm{pH}$, could be measured and increased up to $+30 \mathrm{mV}$ at high vacuolar $\mathrm{pH}$ (Figure $3 \mathrm{~A})$. As $\mathrm{K}^{+}$concentration in the perfusion medium approached the level of the sap $(\sim 100 \mathrm{mM})$, the pump PD was short-circuited (Figure 3A). So, there is an interesting difference between the two membranes: the plasma membrane $\mathrm{H}^{+}$ATPase shuts down, when the membrane conductance becomes dominated by $\mathrm{K}^{+}$channels (Beilby, 1985), while the tonoplast proton pump/s work against high $\mathrm{K}^{+}$conductance background with high $\mathrm{K}^{+}$concentrations $(\sim 100 \mathrm{mM})$ in the cytoplasm and vacuole.

Shimmen and MacRobbie (1987) employed the technique of permeabilization to disintegrate the plasma membrane by removing external and wall $\mathrm{Ca}^{2+}$ by ethylene glycol tetraacetic acid (EGTA). While the chloroplasts were disrupted, the tonoplast and the vacuolar compartment were largely unchanged. The cells were exposed to medium simulating the main features of the native cytoplasm (Shimmen and Tazawa, 1982) and ATP or Pyrophosphate (PPi) concentrations could be controlled. The cells were perfused and their ends ligated prior to permeabilization to control the vacuolar medium and to eliminate its buffering capacity. The $\mathrm{H}^{+}$pumping ability of the tonoplast was judged by accumulation of neutral red in the cell constructs. Shimmen and MacRobbie (1987) found two distinct types of proton pump in the tonoplast, energized either by ATP 
or PPi. The PPase needs $\mathrm{K}^{+}$and $\mathrm{Mg}^{2+}$, does not respond to $\mathrm{NO}_{3}^{-}$ and is less affected by DCCD. The ATPase needs $\mathrm{Mg}^{2+}$ but not $\mathrm{K}^{+}, \mathrm{NO}_{3}^{-}$applied from the cytoplasmic side inhibits its activity and DCCD is a more powerful inhibitor. Both tonoplast pumps can be distinguished from the plasma membrane ATPase, as they are not affected by cytoplasmic vanadate.

\section{I/N Characteristics of Pumps and $\mathrm{Cl}^{-}$Channel}

Tester et al. (1987) permeabilized young Chara leaf cells and measured I/V characteristics between -200 and $+200 \mathrm{mV}$. With low cytoplasmic $\mathrm{Cl}^{-}$, the sigmoid profile crossed the axis at slightly positive $\mathrm{PD}$. A rise in cytoplasmic $\mathrm{Cl}^{-}$concentration from 14 to $64 \mathrm{mM}$ increased the conductance in PD-dependent manner, suggesting opening of $\mathrm{Cl}^{-}$channels (Figure 3B). The equilibrium $\mathrm{PD}$ is positive in this preparation, as the reference electrode was placed in the cytoplasmic phase and the internal electrode in the vacuole. A drop in cytoplasmic $\mathrm{K}^{+}$concentration from 113 to $30 \mathrm{mM}$ increased the tonoplast conductance in several experiments, somewhat contradictory to results of Moriyasu et al. (1984b).

\section{$\mathrm{K}^{+}$Channels}

To utilize new (then) technique of patch clamping, cytoplasmic droplet technique was developed by Luhring (1986) using results from Moriyasu et al. (1984a). A cut end of a slightly flaccid internodal cell was immersed in the vacuolar sap-like medium, producing droplets, which did not form cell walls. Sakano and Tazawa (1986) demonstrated the vacuolar origin of the membrane by fluorescence after perfusion with Concanavalin A/fluorescein isothiocyanate (FITC). The droplets were very stable and accessible to patch-clamp electrodes in both dropattached and excised configurations.

Luhring (1986), Laver and Walker (1987) and Laver et al. (1989) made detailed studies of the conductive (170 pS) $\mathrm{K}^{+}$ channel in the droplets. Laver and Walker (1987) formulated mathematical model with one fully open state and seven closed states. The average I/V characteristics exhibited a maximum between -100 and $-200 \mathrm{mV}$, somewhat puzzling result, as tonoplast $\mathrm{PD}$ is usually positive (Figure 3C). Laver and Walker (1991) described channel activation by cytoplasmic $\mathrm{Ca}^{2+}$ concentration from $0.1-1 \mu \mathrm{M}$, with three bound calcium ions necessary for opening. However, for cytoplasmic $\mathrm{Ca}^{2+}$ concentrations above $10 \mu \mathrm{M}, \mathrm{Ca}^{2+}$ could act as a block. Laver (1992) distinguished two binding sites for $\mathrm{Ca}^{2+}$ in the vestibule to the vacuole and three binding sites for $\mathrm{Ca}^{2+}$ on the cytoplasmic side. Laver et al. (1997) observed that calmodulin inhibitors W-7 and trifluoperazine (TFP) affected the channel open state, with TFP promoting a new sub-state, but the channel was not $\mathrm{Ca}^{2+}$-calmodulin activated. Homble and Fuks (1991) observed partial block by tetraethylammonium (TEA) on either side of the membrane. Bertl (1989) replaced $\mathrm{K}^{+}$by $\mathrm{Na}^{+}$, blocking the channel on either side of the tonoplast. The addition of $\mathrm{Na}^{+}$ to $\mathrm{K}^{+}$resulted in regions of negative conductance. Tyerman et al. (1992) resolved conductance sub-states: a longer residency located near the main open state, while a "mid-state" occurred after fast transitions from the main state. Draber et al. (1993) and Schultze and Draber (1993) detected spontaneous cooperative behavior of $\mathrm{K}^{+}$channels that might arise from channel clustering in the membrane. Katsuhara et al. (1989) suggested that $\mathrm{Ca}^{2+}$ dependent $\mathrm{K}^{+}$currents across the tonoplast have an important role in hypotonic regulation in salt tolerant Lamprothamnium succinctum.

Another type of $\mathrm{K}^{+}$channel with smaller conductance ( $90 \mathrm{pS}$ ) was also observed in tonoplast droplets (Tyerman and Findlay, 1989; Pottosin and Andjus, 1994). Pottosin and Andjus (1994) patch-clamped droplets of C. gymnophylla and classified these channels as slow delayed rectifier, activated by depolarization, not high $\mathrm{Ca}^{2+}$ and blocked by TEA, and Cs ${ }^{+}$. The authors suggested a role for repolarization after excitation event.

\section{$\mathrm{Cl}^{-}$Channels}

The $\mathrm{Cl}^{-}$channels with a conductance of $\sim 21 \mathrm{pS}$ were also detected in the droplets (Tyerman and Findlay, 1989). In droplet attached mode with media of $130 \mathrm{mM} \mathrm{Cl}^{-}$outside and $\sim 15 \mathrm{mM}$ $\mathrm{Cl}^{-}$inside the channel behaved as an outward rectifier. The rectification disappeared in symmetrical $\mathrm{Cl}^{-}$concentrations in detached patches. Berecki et al. (1999) measured channel activation by increased cytoplasmic (but not vacuolar) $\mathrm{Ca}^{2+}$ concentration. $\mathrm{ZnCl}_{2}(5-10 \mu \mathrm{M})$ acted as a block from cytoplasmic side. If the membrane PD was held negative of the reversal $\mathrm{PD}$, larger negative currents were recorded, while preclamping to more positive PD produced larger positive currents. Low channel activity was observed at the normal cytoplasmic $\mathrm{pH}$ (7.2 - 7.4) with a half-maximal $\mathrm{Ca}^{2+}$ concentration of $100-$ $200 \mu \mathrm{M}$ (Berecki et al., 2001). At lower pH 6.0 the channel activity and mean open times became maximized at positive PDs and lower half-maximal activating $\mathrm{Ca}^{2+}$ concentration $(5 \mu \mathrm{M})$, perhaps due to better calcium binding. Beilby et al. (1999) found more $\mathrm{Cl}^{-}$channels in tonoplast of Lamprothamnium sp. as the external sulphated polysaccharide mucilage increased with cell age.

\section{Comparison to Land Plant Tonoplast Transporters}

The vacuolar ATPases were discovered in animal, fungi and land plant experimental systems. In land plants the proton pumping function was measured in late 1970 and early 1980s (see Beyenbach and Wieczorek, 2006 for historical account). The PPase was discovered in 1960s (see Hedrich and Schroeder, 1989 for review), but the proton pumping function was also realized later (Rea and Sanders, 1987). So, the elegant experiments of Moriyasu et al. (1984a,b) and Shimmen and MacRobbie (1987) confirmed results from isolated vacuoles and microsomes and placed it in evolutionary context. The sigmoid I/V characteristics observed for short periods in some experiments by Tester et al. (1987) may have been first recorded I/V characteristics of the vacuolar $\mathrm{H}^{+}$pumps (compare Figure 3B with simulations from OnGuard model, Blatt et al., 2014). While in many of their experiments the ATP or PPi was not supplied in the permeabilizing medium, small amounts could have been retained near the vacuolar membrane. This experimental system clearly needs revisiting. Nakanishi et al. (1999) found the cDNA sequence of the C. corallina PPase $71 \%$ identical to that of land plants and $46 \%$ identical to 
that of chlorophyte Acetabularia and phototropic bacterium Rhodospirillum rubrum.

The vacuolar channels in land plants have been classified as slow activating (SV), fast activating $(\mathrm{FV})$ and $\mathrm{K}^{+}$selective $(\mathrm{VK})$ (for review se Hedrich, 2012). The VK channel group includes two-pore channels (TPK). Patch clamp studies identified SV as non-selective cation channel, permeable to $\mathrm{Na}^{+}$and under some conditions to $\mathrm{Ca}^{2+}$, which needs elevated cytoplasmic calcium level to open. In Arabidopsis genome TPC1 encodes the SV channel and loss of function mutants indicated that SV controls $\mathrm{K}^{+}$homeostasis of the cell. Anion channels appear to be controlled by cell biochemistry and have been observed under elevated cytoplasmic calcium and in presence of kinases. CLC channels described in Arabidopsis genome operate as vacuolar anion channels or proton- $\mathrm{Cl}^{-}$antiporters. Also in Arabidopsis the ALMT6 channels transport malate across the tonoplast. The SV channels seem to have appeared soon after plants came to land, as they were observed in patch clamp studies of Physcomitrella patens tonoplast (Koselski et al., 2013), but not in Characeae. In vascular land plants vacuoles have diversified to fulfill different functions in specialized tissues: for instance protein storage in a seed, storage of nitrogen in root tip, shrinking or swelling in stomata, storage of sulfate or storage of malate for crassulacean acid metabolism (CAM) photosynthesis (Martinoia et al., 2007). It will be interesting to compare sequences of $\mathrm{K}^{+}, \mathrm{Cl}^{-}$and specialized channels in Characeae and land plants.

\section{Cytoplasmic Perfusion, Combination of Flux and Electric Current Measurement, Increasing the Size of Cytoplasmic Layer: Plasma Membrane Transporters}

The tonoplast can be swept away by increasing the rate of perfusion flow or including EGTA in the medium (Williamson, 1975; Tazawa et al., 1976; Figure 2C). The experimenter now has access to both sides of the plasma membrane. The cell can be repeatedly perfused if the ends are left open. Alternatively, the ends are ligated and electrical contact is made by impaled electrode. In each case the cells are fragile and live only for some hours.

\section{$\mathrm{Cl}^{-} / \mathrm{H}^{+}$Symporter}

With the negative membrane PD across the plasma membrane, $\mathrm{Cl}^{-}$needs active transport into the cell even with the low concentration in the cytoplasm. Cells concentrate $\mathrm{Cl}^{-}$in the vacuoles as osmoticum and to keep electroneutrality. Sanders (1980a) found an increase in $\mathrm{Cl}^{-}$influx following period of $\mathrm{Cl}^{-}$"starvation." Membrane PD transiently depolarized upon resupply of $\mathrm{Cl}^{-}$in the medium (Figure 4A). Using perfused tonoplast-less cells he established that this flux stimulation resulted from drop of cytoplasmic $\mathrm{Cl}^{-}$concentration. He also observed a strong dependence of $\mathrm{Cl}^{-}$influx on cytoplasmic and external pH (Figure 4B; Sanders, 1980b). The control of the cytoplasmic phase facilitated resolution of the change in $\Delta_{\mu \mathrm{H}}$, influence of external $\mathrm{pH}$ on cytoplasmic $\mathrm{pH}$ and the lack of influence of cation fluxes of $\mathrm{K}^{+}$or $\mathrm{Na}^{+}$(earlier postulated salt pump - Findlay et al., 1969). Beilby and Walker (1981) demonstrated instantaneous manifestation of $\mathrm{Cl}^{-}$influx by voltage-clamping the membrane $\mathrm{PD}$ of $\mathrm{Cl}^{-}$-starved Chara cell, challenging the cell with a range of low concentrations of $\mathrm{Cl}^{-}$and recording an inward positive current (Figure 4C). Clamping the membrane PD prevented activation of other transporters by change in $\mathrm{PD}$. The current amplitude leveled off with Michaelis-Menten kinetics $\left(\mathrm{V}_{\mathrm{m}} \sim 100 \mathrm{nmol} / \mathrm{m}^{2} . \mathrm{s}\right.$, $\left.\mathrm{K}_{\mathrm{m}} 10-20 \mu \mathrm{M}\right)$. Beilby and Walker (1981) modeled the data with the Hill-Whittingham equation, which is appropriate for processes with low $\mathrm{K}_{\mathrm{m}}$ where an unstirred layer may be important. Sanders (1980b) and Beilby and Walker (1981) agreed that $\mathrm{Cl}^{-}$is co-transported with $2 \mathrm{H}^{+}$, with net positive charge influx.

Sanders and Hansen (1981) formulated a kinetic model, where three reaction steps occur on either surface of the plasma membrane and loaded or unloaded carrier crosses the membrane. This scheme postulates that $\mathrm{Cl}^{-}$binds on and leaves first and charge crosses membrane on loaded carrier. The model addresses the main features of the symporter: (i) MichaelisMenten kinetics, (ii) cytoplasmic $\mathrm{Cl}^{-}$concentration and $\mathrm{pH}$ effects on $\mathrm{V}_{\max }$ but not $\mathrm{K}_{\mathrm{m}}$, and (iii) $\mathrm{Cl}^{-}$concentration and $\mathrm{pH}$ interaction.

\section{Amine Uniporter}

Nitrogen is vital for many important plant biochemicals, such as chlorophyll, ATP, nucleic and amino acids. Smith and Walker (1978), Walker et al. (1979a,b) found that simple amines enter characean cells as cations, $\mathrm{NH}_{4}{ }^{+}$and $\mathrm{CH}_{3} \mathrm{NH}_{3}{ }^{+}$, at $\mathrm{pH}$ below their respective $\mathrm{pK}_{\mathrm{a}}$ of 9.25 and 10.64 . Using similar technique to $\mathrm{Cl}^{-}$influx investigation, Walker et al. (1979a) challenged the cell with a range of amine concentrations and recorded clamp currents, also obtaining Michaelis-Menten relationship: $\mathrm{V}_{\mathrm{m}}$ up to $200 \mathrm{~mA} / \mathrm{m}^{2}$, low $\mathrm{K}_{\mathrm{m}}$ of $\sim 3 \mu \mathrm{M}$ for $\mathrm{NH}_{4}^{+}$and $200 \mu \mathrm{M} \mathrm{CH} \mathrm{CH}_{3}^{+}$. Clamping at different membrane PDs established exponential PD dependence of both $V_{m}$ and $K_{m}$. The Hill-Whittingham equation yielded unstirred layer of up to $150 \mu \mathrm{m}$ in slow flowing media, which reduced to $\sim 40 \mu \mathrm{m}$ in fast flowing media. The rate of transport fell rapidly with exposure to amines (At one time all Characeae cultures in the laboratory stopped reacting to amines and experiments could only be restarted after enthusiastic cleaning lady stopped mopping the lab floor with ammonium based cleaner!). The transporter was modeled as a uniport with a binding site inside the membrane and mid membrane potential energy barrier. Fairley and Walker (1987) concluded that increasingly substituted amines are transported in cationic form by the same porter. The stoichiometric ratio of the influx of charge and ${ }^{14} \mathrm{C}$ methylamine was $0.9 \mathrm{~mol} /$ Faraday $(\mathrm{pH} 5.7-8.5)$. Above $\mathrm{pH} 9$, the influx of amine increased with rising concentrations of the free bases (Walker et al., 1979b; Figure 5A). Ritchie (1987) measured permeabilities of ammonia, methylamine and ethylamine as $\mathrm{P}_{\text {ammonia }}=(6.4 \pm 0.93) \times 10^{-6} \mathrm{~m} / \mathrm{s}, \mathrm{P}_{\mathrm{MA}}=(6.0 \pm 0.49) \times 10^{-6}$ $\mathrm{m} / \mathrm{s}$ and $\mathrm{P}_{\mathrm{EA}}=(8.4 \pm 1.2) \times 10^{-6} \mathrm{~m} / \mathrm{s}$ to $(14 \pm 1.2) \times 10^{-6}$ $\mathrm{m} / \mathrm{s}$. The $\mathrm{pH}_{\mathrm{o}}$ in the alkaline bands is close to the $\mathrm{pK}_{\mathrm{a}}$ of these amines $(9.25$ - 10.75), so the neutral amine transport is important. Ryan and Walker (1993) measured ammonium 

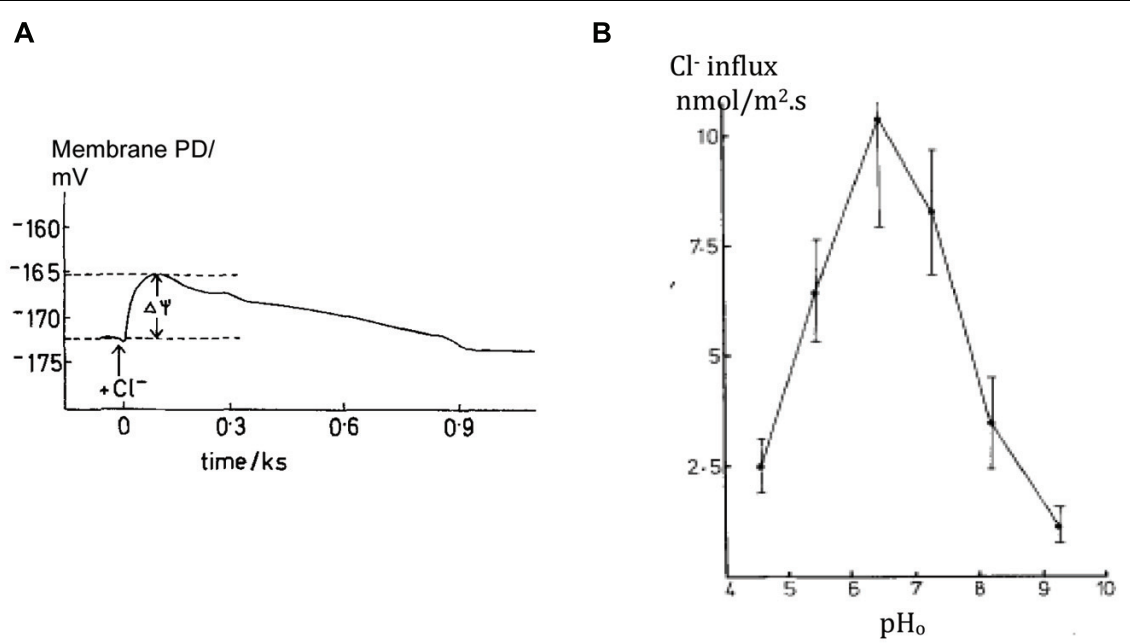

C

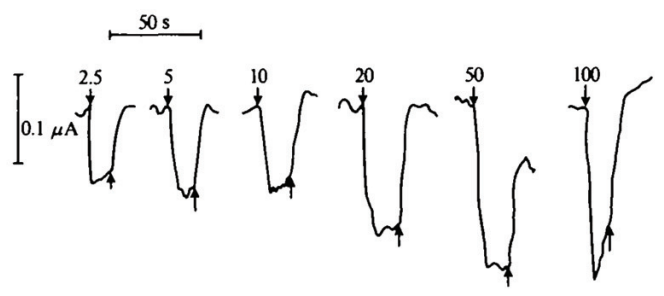

FIGURE 4 | Plasma membrane transporters: $\mathrm{Cl}^{-} / \mathrm{H}^{+}$symporter. (A) Chara cell Membrane PD depolarization upon re-supplying $\mathrm{Cl}^{-}$after overnight starvation, see arrow (Sanders, 1980b) (B) Chloride influx in intact cells as function of external medium pH, pHo (Sanders, 1980b). (C) Positive inward currents observed in Chara cells with their resting PD voltage-clamped upon exposure to range of $\mathrm{Cl}^{-}$concentrations shown next to each pulse in $\mu \mathrm{M}$ (Beillby and Walker, 1981).

concentration in Chara vacuole of up to $70 \mathrm{mM}$, mostly in protonated form due to low vacuolar $\mathrm{pH}$. To preserve electroneutrality, cells exported $\mathrm{K}^{+}$and $\mathrm{Na}^{+}$and imported $\mathrm{Cl}^{-}$or manufactured malate in $\mathrm{Cl}^{-}$- free media. Ryan and Walker (1994) inhibited Glutamine synthase, enzyme involved in ammonia assimilation, by L-methionine-D, L-sulphoximine (MSX). An increased concentration of ammonia in the cell strongly inhibited amine uptake, suggesting kinetic regulation by the internal amine concentration or a concentration of an intermediate of nitrogen assimilation.

\section{Phosphate Transport}

Phosphorus is another vital element for building blocks of plant biochemistry: phospholipids in cell membranes, phosphate groups in DNA and RNA, ATP and other metabolic compounds in energy transduction. Inorganic phosphorus, $\mathrm{Pi}$, forms phosphates: mainly $\mathrm{H}_{2} \mathrm{PO}_{4}^{-}$at $\mathrm{pH} 5$, while $\mathrm{HPO}_{4}^{2-}$ dominates at $\mathrm{pH}$ 10. The observed $\mathrm{Pi}$ concentration of $5-10 \mathrm{mM}$ in the cytoplasm must be maintained by active import, especially as the external concentration is in the micromolar range (Mimura, 1999). Even at this low external Pi, starvation of up to 10 days increased the influx transiently. In contrast to $\mathrm{Cl}^{-}$concentration dynamics, the cytoplasmic Pi concentration did not change with starvation or when $\mathrm{Pi}$ was re-supplied, although the vacuolar concentration increased when Pi was available (Mimura et al., 1998). The membrane PD or the cytoplasmic pH was not affected by $\mathrm{Pi}$ starvation. However, the rate of Pi influx increased for up to 7 days after Pi was re-supplied (Mimura et al., 2002). If the starvation medium contained small amount of Pi (0.5$1 \mu \mathrm{M})$ the response was greater, but more transient. The $\mathrm{Pi}$ influx showed two plateaux, as the Pi concentration increased and was modeled by a low affinity transporter with $\mathrm{K}_{\mathrm{m}}$ of $\sim 4 \mu \mathrm{M}$ and a higher affinity transporter with $\mathrm{K}_{\mathrm{m}}$ of $\sim 220 \mu \mathrm{M}$ (Mimura et al., 1998; Figure 5B). $\mathrm{Pi}$ and $\mathrm{Na}^{+}$uptakes were linked: $\mathrm{Na}^{+}$concentration with $\mathrm{K}_{\mathrm{m}}$ of $300 \mu \mathrm{M}$, Pi concentration with $\mathrm{K}_{\mathrm{m}}$ of $10 \mu \mathrm{M}$. In absence of external $\mathrm{Na}^{+}$induction and inactivation were abolished. Thus $\mathrm{Na}^{+}$is the main cotransported ion (Mimura et al., 1998; Reid et al., 2000). Combined tracer and voltage clamp experiments established the stoichiometry of $\mathrm{Na}: \mathrm{Pi}$ of 5.68 at $\mathrm{pH}_{\mathrm{o}}$ 6. The stoichiometry was confirmed by voltage-clamp experiments where the influx of positive charge exceeded the influx of ${ }^{32} \mathrm{Pi}$ by a factor of 6.26. The dependence of $\mathrm{Pi}$ influx on $\mathrm{pH}_{\mathrm{o}}$ is consistent with the transported species being $\mathrm{H}_{2} \mathrm{PO}_{4}^{-}$. Interestingly, perfused cells required ATP in the perfusion medium to reach a similar influx of $\mathrm{Pi}$ to that of intact cells. It is possible that hyperpolarization is necessary for this symport to function. While the electrochemical $\mathrm{PD}$ for $\mathrm{H}_{2} \mathrm{PO}_{4}^{-}$ and $\mathrm{Na}^{+}$suggests that there is not enough energy at $\mathrm{pH}_{\mathrm{o}} 5$, a large influx was still observed. The authors suggest that the symporter might be able to utilize $\mathrm{H}^{+}$at low external $\mathrm{pH}$, as observed in yeast and Neurospora (see Reid et al., 2000 for review). 


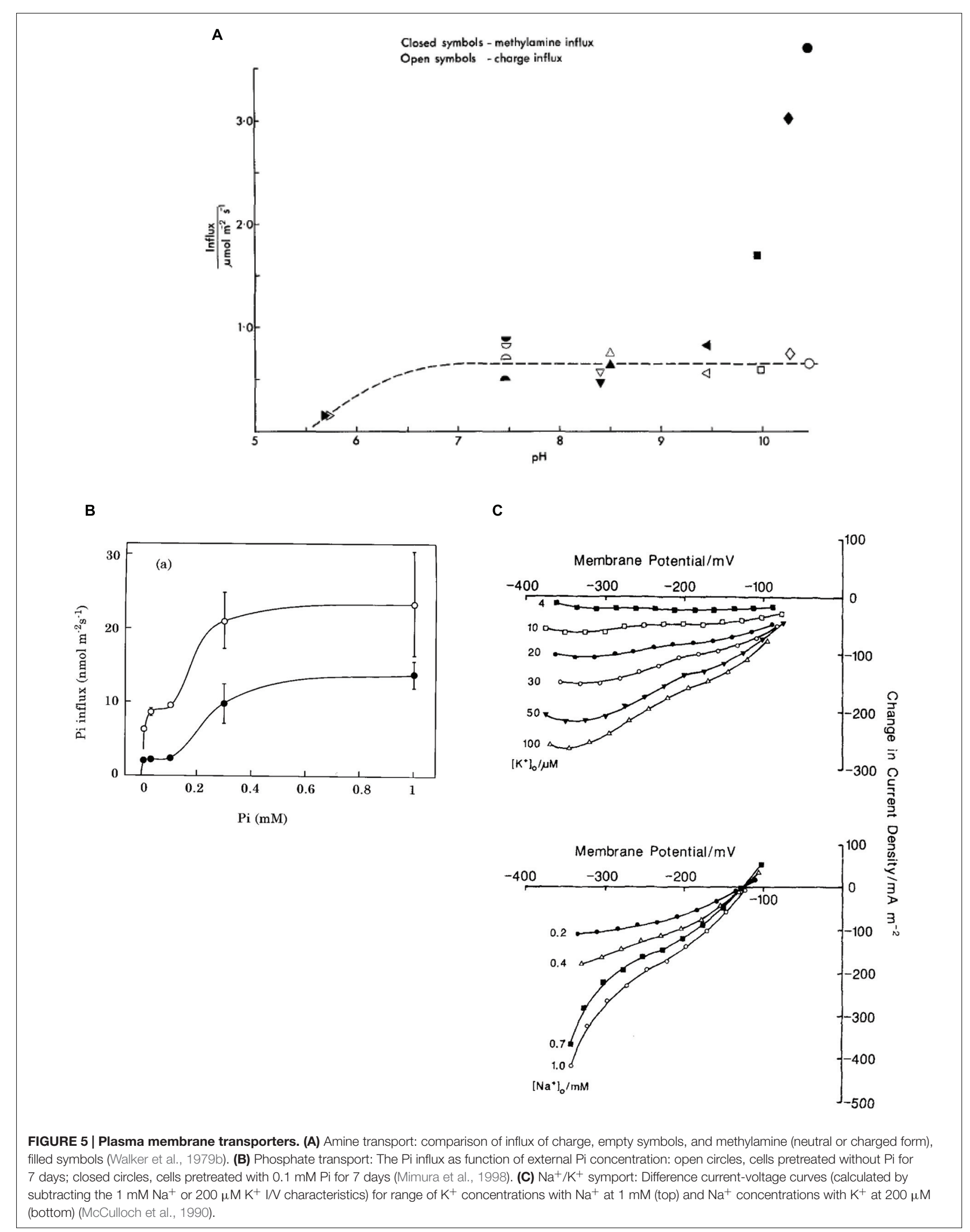




\section{$\mathrm{Na}^{+} / \mathrm{K}^{+}$Transport}

Similar to phosphate, $\mathrm{K}^{+}$is concentrated in both cytoplasm and vacuole (up to $\sim 100 \mathrm{mM}$ ), but may be quite scarce in some ponds inhabited by freshwater Characeae. The $\mathrm{K}^{+}$selective inward rectifier channels require very negative membrane PDs to open. The high conductance $\mathrm{K}^{+}$channels open at less negative membrane PDs, but need external $\mathrm{K}^{+}$concentrations above $\sim 1 \mathrm{mM}$. After the cells were starved of $\mathrm{K}^{+}$, Smith and Walker (1989) measured electrogenic influx of $\mathrm{K}^{+}$, which was dependent on $\mathrm{Na}^{+}$presence in the medium. The ratio of tracer and charge inflow confirmed symport of $\mathrm{K}^{+}$with $\mathrm{Na}^{+}$with a stoichiometry 1:1: $\mathrm{K}^{+}$with $\mathrm{K}_{\mathrm{m}}$ of $\sim 30 \mu \mathrm{M}$ and $\mathrm{Na}^{+}$with $\mathrm{K}_{\mathrm{m}}$ of $\sim 470 \mu \mathrm{M}$. McCulloch et al. (1990) observed an exponential clamp current turnoff with short half times of $\sim 50 \mathrm{~s}$, even in low $\mathrm{K}^{+}$concentrations. As $\mathrm{K}^{+}$concentration in the cytoplasm is already high, $\mathrm{Na}^{+}$was a more likely candidate for transport inhibition at $\sim 5 \mathrm{mM}$ (Tazawa et al., 1974). The authors used cytoplasm-enriched fragments to overcome current turnoff and gain more time for measurements. These cell constructs are prepared by slow centrifugation of long internodal cells creating cytoplasmic plug at one end, which is then tied off by a thread. With greater volume of cytoplasm for a given surface area, it was possible to obtain families of I/V characteristics at different $\mathrm{K}^{+}$and $\mathrm{Na}^{+}$concentrations (see Figure $5 \mathrm{C}$ ). For $\mathrm{K}^{+}$influx, $\mathrm{K}_{\mathrm{m}}$ decreased as the $\mathrm{PD}$ became more negative, while $\mathrm{V}_{\max }$ increased. For a $\mathrm{Na}^{+}$influx both $\mathrm{K}_{\mathrm{m}}$ and $\mathrm{V}_{\max }$ increased with the negative going $\mathrm{PD}$. These characteristics can be modeled either by simultaneous transit of $\mathrm{K}^{+}$and $\mathrm{Na}^{+}$, or by the ions transiting in consecutive steps. Both models suggest a double negative charge on the unloaded carrier and extracellular binding of $\mathrm{K}^{+}$followed by $\mathrm{Na}^{+}$. The charge transit process is the limiting step at more positive membrane PDs.

\section{Comparison to Land Plant Plasma Membrane Transporters}

The $\mathrm{H}^{+} / \mathrm{Cl}^{-}$symporter in root hair cells of Arabidopsis relative mustard Sinapis alba was described by Felle (1994). Clearly, this transporter must be active in range of tissues of land plants, as $\mathrm{Cl}^{-}$compartmentation is similar to Characeae: low in the cytoplasm and high in the vacuole to maintain turgor together with $\mathrm{K}^{+}$and other inorganic and organic anions (Barbier-Brygoo et al., 2000). Teakle and Tyerman (2010) lament lack of data on $\mathrm{Cl}^{-}$transport under salinity stress. They point out that the electrochemical potential for $\mathrm{Cl}^{-}$changes as plants are exposed to saline environment and the $\mathrm{Cl}^{-}$influx might become passive through channels. The salt tolerant Characeae Lamprothamnium increases its vacuolar $\mathrm{Cl}^{-}$concentration from $200-800 \mathrm{mM}$ as external salinity rises (Bisson and Kirst, 1980). This is a perfect system to study the nature of $\mathrm{Cl}^{-}$inflow under salinity stress.

The ammonium ion transporters belong to the AMT/MEP/Rh family found in all domains of life and described in plants and fungi in 1990s (for reviews see Ludewig et al., 2007; McDonald et al., 2011). The detailed protein structures are being investigated and suggest charged $\mathrm{NH}_{4}{ }^{+}$is the transported molecule (Pantoja, 2012).

In phosphate transport, most land plants use $\mathrm{H}^{+}$as the driver ion and Pi uptake causes cytoplasmic acidification (Mimura,
2001). The main family of Pi transporters are PHT1 (see Nussaume et al., 2011 for review). The $\mathrm{Na}^{+} / \mathrm{Pi}$ transporter in Characeae is similar to that in animal cells, which operate on $\mathrm{Na}^{+}$economy. However, there are examples of $\mathrm{Na}^{+} / \mathrm{Pi}$ symport in some chlorophytes (Ullrich and Glasser, 1982; Ritchie et al., 1997).

$\mathrm{Na}^{+} / \mathrm{K}^{+}$symport is limited to aquatic higher plants and was observed in Egeria and Vallisneria leaves, and in Elodea and Egeria roots. In land plants such as wheat, barley or Arabidopsis, the driver ion appears to be $\mathrm{H}^{+}$(Maathuis et al., 1996). In Characeae the $\mathrm{Na}^{+}$coupling is also implicated in the transport of urea, amino acids and sugars (Walker et al., 1993; Walker, 1994).

The detailed data on the control of the above transport systems by external and internal concentrations of driver and transported substances and $\mathrm{pH}$ were obtained utilizing the large size of characean cells and the ability to manipulate cellular compartments by perfusing the vacuole or the cytoplasm or concentrating the cytoplasm in the cytoplasm enriched cell constructs. Direct comparison of tracers and electrical currents in voltage clamped cells provided transport stoichiometries.

\section{Cell to Cell Transport \\ Structure of Nodal Complex}

The axial and branch internodes are separated by nodal complexes (see Figure 6A, Walker and Bostrom, 1973). Shepherd and Goodwin (1992b) describe how the new internode and the nodal architecture arise from the apical cell establishing the path of cytoplasmic streaming (see Streaming). The shortest path between two internodal cells is through two flat cells in the middle of the node (marked "C" in Figure 6A, Spanswick and Costerton, 1967).

Transport between internodal cells is mediated, and controlled, by plasmodesmata that connect the cytoplasm of neighboring cells (for review see Burch-Smith and Zambryski, 2012). Spanswick and Costerton (1967) found that in Nitella translucens the plasmodesmata between the nodal cells had uniform diameter, while plasmodesmata between nodal and internodal cells developed central cavities, sometimes with several openings. Young cells exhibited extensive connectivity with up to $14.7 \%$ of the wall occupied by plasmodesmata. Characeae form primary plasmodesmata containing endoplasmic reticulum (ER) with close similarity to higher plant plasmodesmata was established (Franceschi et al., 1994; Cook et al., 1997; Brecknock et al., 2011; Figure 6B).

\section{Fluorescent Tracers}

Shepherd and Goodwin (1992a,b) attached peptides of increasing molecular weight to fluorescein to establish molecular exclusion limit in cell to cell communication: $874 \mathrm{Da}$. They used young shoots of C. corallina and injected fluorescein by iontophoresis, sometime aided by pressure, into the cytoplasm of one of the cells in a lateral branch. In the winter months the lateral internode cells exhibited low resting $\mathrm{PD}$ of $\sim-120 \mathrm{mV}$ and restricted cell-to-cell communication of the internode and adjacent node. As the action potential inhibited cell-to-cell communication, the exposure to excitation inhibitor $\mathrm{La}^{3+}$ restored communication. In spring the branch cells with more negative resting $\mathrm{PD}(\sim$ 
A

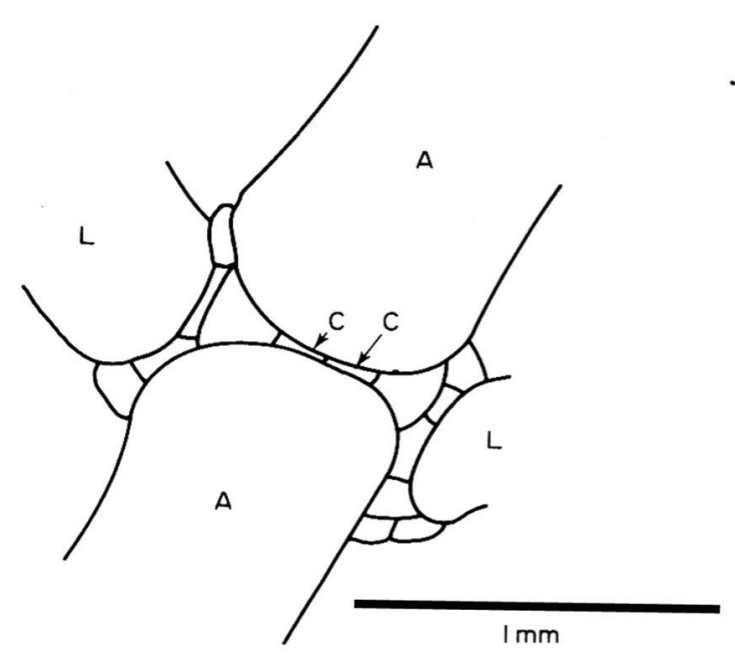

B



C

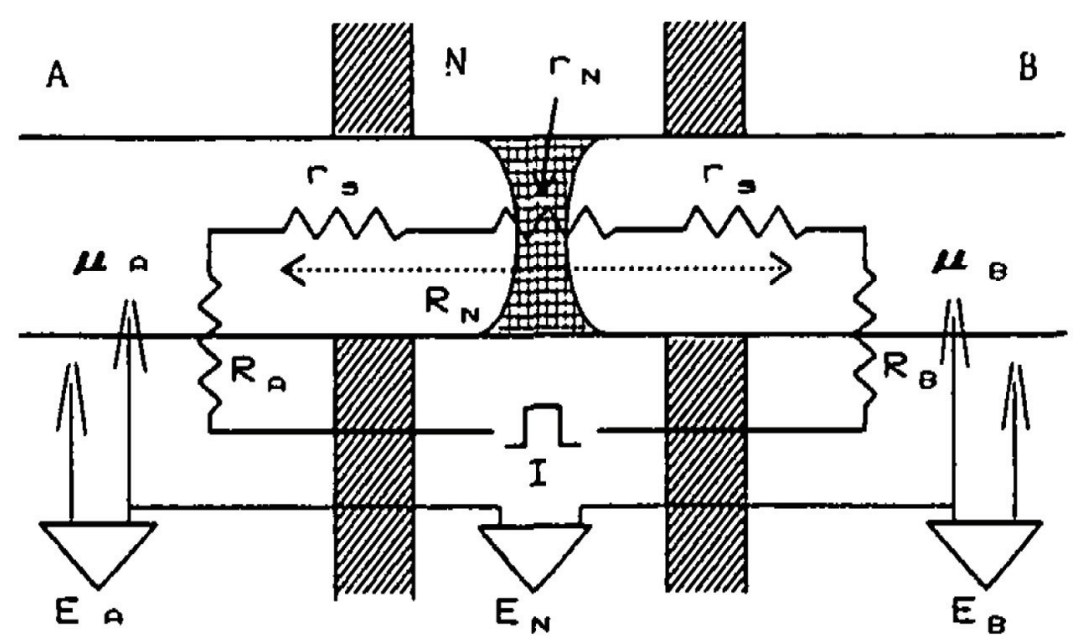

FIGURE 6 | Structure of the nodal complex. (A) In this diagram of longitudinal section through the node of Chara the axial internodes are marked "A," the lateral (leaf) internodes are marked "L" and the two central nodal cells are labeled "C." (adapted from Walker and Bostrom, 1973). (B) Electron microscopy of transverse view of plasmodesma in a branch node of C. zeylanica. Arrow marks the central desmatubule, small arrowheads indicate the spoke structures connecting it to plasma membrane. Bar is $50 \mathrm{~nm}$ (from Cook et al., 1997). (C) The electrical model of the node and its neighboring internodes (Ding and Tazawa, 1989): $R_{A}$ is the membrane resistance of cell $A, R_{B}$ is the membrane resistance of cell $B, R_{N}$ is the resistance across the node, which is the sum of the node resistance $r_{N}$ plus the resistances of the cell sap $r_{s}$. The PDs across cell $A$, cell $B$ and the nodal region are $E_{A}, E_{B}$ and $E_{N}$, respectively. The internal electrodes are labeled $\mu_{A}$ and $\mu_{B}$.

$-210 \mathrm{mV}$ ) increased transport of 6 carboxyfluorcescein between nodes and internodes. As in winter cells, if cytoplasmic $\mathrm{Ca}^{2+}$ was increased due to action potential or exposure to ionophore A23187, cell-to-cell transport was inhibited.
The spring plants became fertile and formed male reproductive structures (antheridia) from the nodal cells located near the descending (internodal) cytoplasmic stream. While the molecular exclusion limit was smaller (between 750 
and $874 \mathrm{Da}$ ), the young antheridia were easily reached by the fluorescent dye, while the mature antheridia lost connectivity from the rest of the plant (Shepherd and Goodwin, 1992b).

Kwiatkowska (2003) combined fluorescent dye Lucifer Yellow experiments with electron microscopy to study the development of the antheridia in C. vulgaris and tomentosa. Simple plasmodesmata connect the antheridium and supporting cells in early developmental stages. Gradually some plasmodesmata disappeared enforcing radial orientation of symplasmic routes through the antheridium. Simple plasmodesmata developed branching to provide pathway for gibberellins and nutrients. Then the plasmodesmata were selectively plugged, limiting the synchronization of cell divisions. Finally the plasmodesmata between the antheridium and the thallus were spontaneously broken, starving the antheridium of gibberellins and initiating spermiogenesis. ER penetrated into antheridial filament plasmodesmata at specific stage of spermiogenesis enabling exchange of nucleohistones into nucleoprotamines. These results confirm that the plasmodesmata are very dynamic structures under tight control of the plant.

\section{Radioactive or Substitution Tracers}

Bostrom and Walker (1975) employed two internodal cells in tandem to measure the intercellular transport of $\mathrm{Cl}^{-}$. The cells were placed in three-compartment holder similar to that in Figure 2A. The node was positioned in the middle compartment (B) and compartments were insulated by silicone grease. The ${ }^{36} \mathrm{Cl}$ tracer was added to one compartment and the content of the tracer in both cells was monitored over time. The chloride was taken up and about two thirds remained in the vacuole of the exposed cell, while a third was transported to the other internode. No polarity was found, as the results were insensitive to swapping the basal and apical internodes as input cells. The rate of transport varied between 4 and 60 pmol.s ${ }^{-1}$ and was consistent with diffusion through the plasmodesmata without invoking bulk flow or active transport. Bostrom and Walker (1976) controlled the speed of cytoplasmic streaming by cytochalasin B. The intercellular chloride flux was proportional to the streaming speed in the input internode but not the "sink" internode. Streaming speed did not affect the chloride influx in the input cell.

Chloride is not consumed in metabolism or complexed into compounds, but its distribution between cytoplasm and vacuole can be complicated by tonoplast action potentials elicited by handling the cells. MacRobbie $(1969,1975)$ initially postulated vesicle transport to explain the fast appearance of chloride tracer in the vacuole. Later she performed elegant experiments exposing only half of the internodal cell to radioactive label. A blockage of excitation diminished the fast "vesicle transport" phase.

Ding and Tazawa (1989) substituted $\mathrm{Rb}^{+}$for $\mathrm{K}^{+}$and exposed the input cell to $100 \mathrm{mM} \mathrm{RbCl}$ at $5^{\circ} \mathrm{C}$. The low temperature inhibited the transnodal transport and $43 \mathrm{mM} \mathrm{Rb}^{+}$accumulated in the cytoplasm. Upon temperature increase to $25^{\circ} \mathrm{C}, \sim 12 \%$ was transported into the sink cell, suggesting diffusion process with coefficient $2.3 \times 10^{-11} \mathrm{~m}^{2} . \mathrm{s}^{-1}$ (plasmodesmata were assumed to occupy $10 \%$ of the nodal area). The rubidium transport was also strongly dependent on cytoplasmic streaming in either or both internodes, regardless if the streaming speed was controlled by cytochalasin $\mathrm{B}$ or change in temperature. A turgor pressure gradient of $240 \mathrm{mOsm}$ across the node decreased the nodal transport, suggesting the existence of valving system.

Zawadski and Fenson (1986a) measured intercellular transport of dissolved inorganic carbon (DIC) by supplying $\mathrm{NaH}^{14} \mathrm{CO}_{3}$ to the input cell. Their results were complicated by the complexity of DIC distribution in the medium as $\mathrm{CO}_{2}$ or bicarbonate according to $\mathrm{pH}$, the intricacy of the banding system (see Beilby and Bisson, 2012) and carbon fixation by photosynthesis. In this case low streaming rate in either cell resulted in diminished intercellular transport. In the winter the transport was more sensitive to anoxia and decrease in illumination. In the summer the cells have greater reserve of ATP, so it is possible that the DIC transport is active. The application of pressure gradients on the node confirmed this hypothesis. Zawadski and Fenson (1986b) found that trans-nodal transport of ${ }^{14} \mathrm{C}$ was independent of the direction of the pressure gradient (up to 2.5 bars). However, the rate of transport decreased with the increasing pressure gradient. The plasmodesmata are likely to contain pressure sensitive valving system. Similar pressure sensitivity was also found in plasmodesmata of higher plants (Oparka and Prior, 1992). Transports of ${ }^{36} \mathrm{Cl},{ }^{32} \mathrm{P}$ and ${ }^{42} \mathrm{~K}$ were also affected by imposed pressure gradients: ${ }^{42} \mathrm{~K}$ transport was consistent with diffusion, but active components were postulated in both ${ }^{36} \mathrm{Cl}$ and ${ }^{32} \mathrm{P}$ transport. Large portion of the ${ }^{32} \mathrm{P}$ in the input cell was metabolized, resulting in small feed into the sink cell. Working with whole plants of C. hispida, Box et al. (1984) measured the flux of ${ }^{14} \mathrm{C}$ from the rhizoids to the top of the plant. The rate of transport was reduced to $6 \%$ by exposure to cytochalasin B. However, transport of ${ }^{32} \mathrm{P}$ was somewhat slower than cytoplasmic streaming probably due to involvement in metabolism. Trebacz et al. (1988) found that blockers of photosystem I or II, such as 3-(3,4-Dichlorophenyl)1,1-dymethylurea (DCMU), 2,6-Dichlorophenolindophenol (DCPIP) or uncouplers of phosphorylation Iodoacetamide (IAc) 2,4-Dinitriphenol (DNP), Diethyl stilbestrol (DES), $\mathrm{NH}_{4}^{+}$and citrate all diminished intake of DIC and reduced the transport across nodes. These findings suggest that the transport of carbon, chloride and phosphate compounds across the node is at least partially active.

Trebacz et al. (1988) identified pentoses, hexoses and disaccharides formed from the supplied $\mathrm{NaH}^{14} \mathrm{CO}_{3}$ by high performance liquid chromatography in the feed cell. These and small amino acids passed through the node into the adjacent cell. Ding et al. (1992) fed $\mathrm{NaH}^{14} \mathrm{CO}_{3}$ to a branchlet of C. corallina in a internode-branchlet complex and measured photoassimilates after $10 \mathrm{~min}$ in both the source branchlet and the sink internode, using thin-layer chromatography. The main photoassimilates transported were sucrose and amino acids. Transport was aided by downward concentration gradients of sucrose, serine and glutamic acid between the cytoplasm of the branchlet and the internodal cell, which decreased when the apex was detached.

\section{Electrical Measurements}

The insertion of electrodes into the internodes on each side of the node allows measurement of transnodal PD 
and also the transmembrane PD of each internode (with appropriate reference electrodes in each compartment). It is also possible to pass current across the node to measure electrical resistance. The node resistance varied in different systems: $\sim 1.7 \mathrm{k} \Omega . \mathrm{cm}^{2}$ in Nitella (Spanswick and Costerton, 1967), $0.47 \mathrm{k} \Omega . \mathrm{cm}^{2}$ in C. corallina (Bostrom and Walker, 1975), $0.06-0.12 \mathrm{k} \Omega . \mathrm{cm}^{2}$ in the nodes between young branch Chara cells and $0.2-0.51 \mathrm{k} \Omega . \mathrm{cm}^{2}$ in the older branch cells (Reid and Overall, 1992). Ding and Tazawa (1989) measured the nodal resistance/conductance as a function of imposed pressure gradient. The pressure gradient of $180 \mathrm{mOsm}$ diminished the conductance to $\sim 50 \%$, but no further decrease was obtained with further pressure rise. The location of increased electrical resistance was found on the side of the node adjacent to the internode with reduced turgor. Thus the nodal cells deform by bulging out into the less turgid internode closing the valving mechanism. The rubidium trans-nodal flux diminished to $3 \%$ in such conditions. The authors formulated an electrical model of the node and adjacent internodes (see Figure 6C). In similar experiments the exposure of one of the tandem Chara internodes to $100 \mathrm{mM}$ mannitol increased nodal resistance by $40 \%$ (Cote et al., 1987).

The metabolic inhibitor carbonyl cyanide m-chlorophenylhydrazone (CCCP) affected internodes by making the membrane $\mathrm{PD}$ less negative, increasing the membrane resistance and stopping the cytoplasmic streaming (Reid and Overall, 1992). The trans-nodal resistance greatly increased with the same time course. The exposure of one internode to $200 \mathrm{mM}$ mannitol resulted in doubling of the nodal resistance. The fluxes of ${ }^{14} \mathrm{C}$ butyrate and ${ }^{36} \mathrm{Cl}$ were diminished both by CCCP and mannitol. The excision of one internode resulted in rapid resistance increase followed by further slow rise. The cytoplasmic $\mathrm{pH}$ changes induced by butyric acid, $\mathrm{NH}_{4}^{+}$ or methylamine resulted in small effects on the trans-nodal resistance. On the other hand, the trans-nodal resistance was insensitive to changes in light intensity, cytoplasmic calcium concentration changes or trans-nodal PD manipulation.

Sibaoka and Tabata (1981) concentrated on action potential (AP) transmission across nodes of C. braunii. They inserted additional electrode in one of the large nodal cells. The whole nodal cell was not excitable, but the adjacent area of the nodal cell (end-membrane) displayed APs. At the time of AP conduction the stimulated internode produced greater electrotonic depolarization in the next internode without the end-membrane excitation, facilitating the internodeinternode transmission. The authors modeled the internode with three resistances $R_{a}$ (internode $a$ ), $R_{b}$ (internode $b$ ) and nodal resistance $R_{n}$ (compare to more complex model in Figure $6 \mathrm{C}$ ). The coupling ratio for internode a was calculated as $R_{b} /\left(R_{b}+R_{n}\right)$. This ratio increases if $R_{b}>R_{n}$ or if APW (artificial pond water) in the nodal compartment was replaced by more conductive medium of $1 \mathrm{mM} \mathrm{KCl}$ or $10 \mathrm{mM} \mathrm{NaCl}$. $\mathrm{R}_{\mathrm{n}}$ was estimated as $1.2 \mathrm{k} \Omega \cdot \mathrm{cm}^{2}$.

\section{Conclusion}

The early measurements of intercellular transport and electrical conductance provided basis to what is now a large field mainly centered on structure and evolution of plasmodesmata (Burch-Smith and Zambryski, 2012; Evkaikina et al., 2014). In gymnosperms and angiosperms primary plasmodesmata develop at the time of cell division, while secondary plasmodesmata can form between any adjacent cells after cell division. Both primary and secondary plasmodesmata were observed in Characeae, but in different species of Chara (Franceschi et al., 1994; Cook et al., 1997; Brecknock et al., 2011). However, some early land plants such as Selaginellaceae and ferns seem to lack the ability to form secondary plasmodesmata (Evkaikina et al., 2014). Raven (2005) suggests complex evolutionary pathway: independent evolution of plasmodesmata in brown algae, in characean algae, and up to five times (!) in green algae, but not in red algae, haptophytes and dinoflagellates, despite multicellular morphology. In embryophytes plasmodesmata facilitate exchange of miRNA, proteins, and mRNA between adjacent cells in the course of plant development. The full role of characean plasmodesmata is yet to be investigated.

\section{Streaming \\ Streaming and Morphology}

The large size of characean cells makes observation of cytoplasmic streaming easy, requiring only low power microscope. The streaming pattern follows the orientation of the chloroplast rows, tracing a helical path around the cell, the upward and downward streams separated by a chloroplast-free "indifferent zone" (Figure 7A). As the chloroplast rows are fixed in the Characeae, the streaming direction is related to the whole plant development. The oldest leaf cell in each whorl and axillary new shoots grow below the descending cytoplasmic stream. The streams run in opposite directions on each side of the nodal complex (Hope and Walker, 1975). The velocity of streaming is comparatively steady given constant temperature and supply of ATP.

\section{Mechanism: Actin and Myosin}

The ribbon of cytoplasm $(\sim 10 \mu \mathrm{m}$ thick $)$ winds its way around the cell with the same speed, transferring some of the movement to the vacuole. This agitation drops off with the distance into vacuolar sap. Kamiya and Kuroda (1956) prepared cytoplasm-enriched cell constructs (see $\mathrm{Na}^{+} / \mathrm{K}^{+}$ Transport) with greater volume of flowing cytoplasm and observed similar speed decrease further away from the gel (static cytoplasm). The authors proposed the "sliding theory," where the interactions of sol (flowing cytoplasm) and gel surfaces produce the shearing force that moves the sol along. Using light microscopy Kamitsubo (1966) observed rope-like structures on the cytoplasmic side of the chloroplasts. Nagai and Rebhun (1966) and Kersey and Wessells (1976) employed electron microscopy to resolve about 100 microfilaments making up each rope. Kamitsubo (1972) used strong illumination to detach chloroplasts and the cables on a small patch of the cell, strongly inhibiting the streaming. When the cables regenerated, streaming was restored. Palevitz et al. (1974) and Williamson (1974) observed arrowhead structure, found in animal systems with actin, when heavy mero-myosin (HMM) sub fragment S1 
A

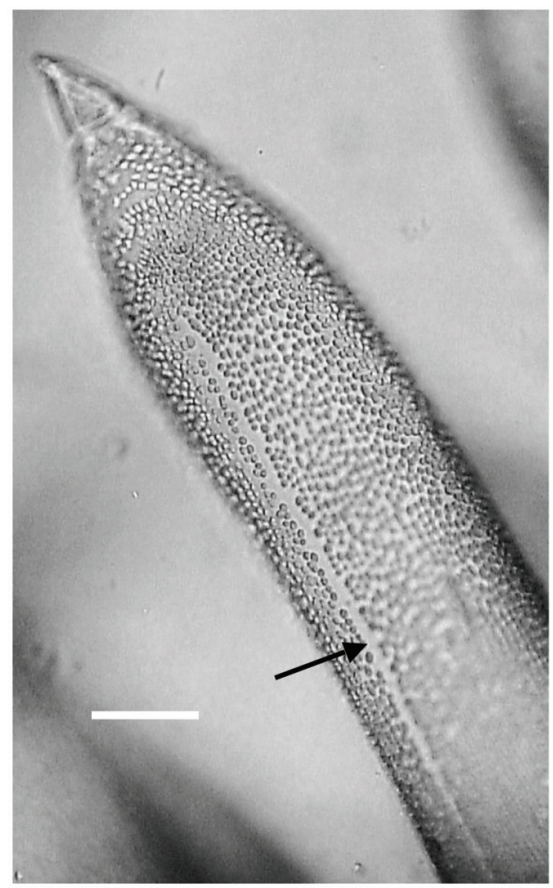

B
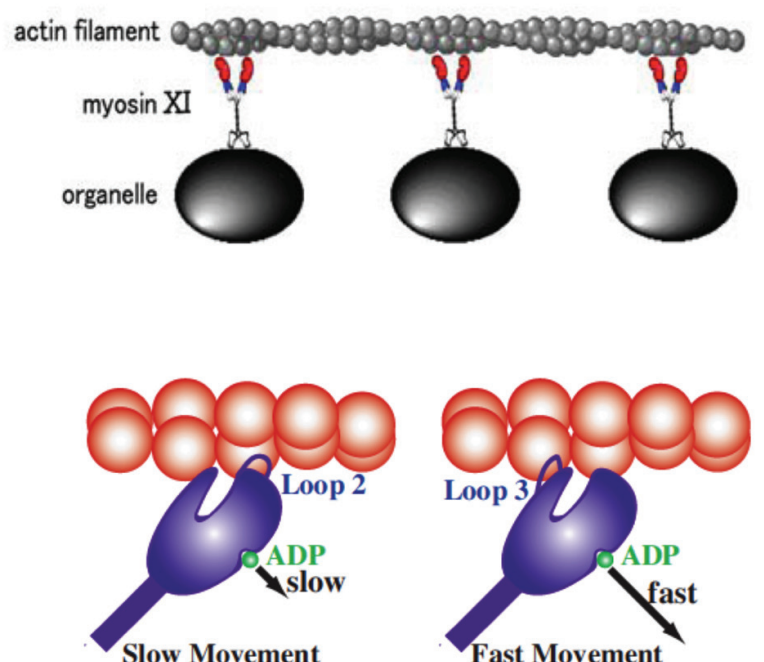

Most myosins

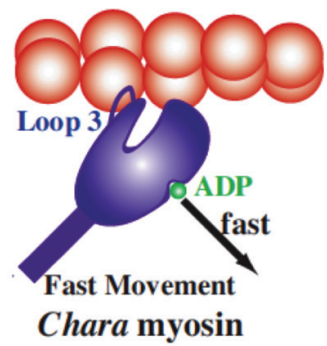

C
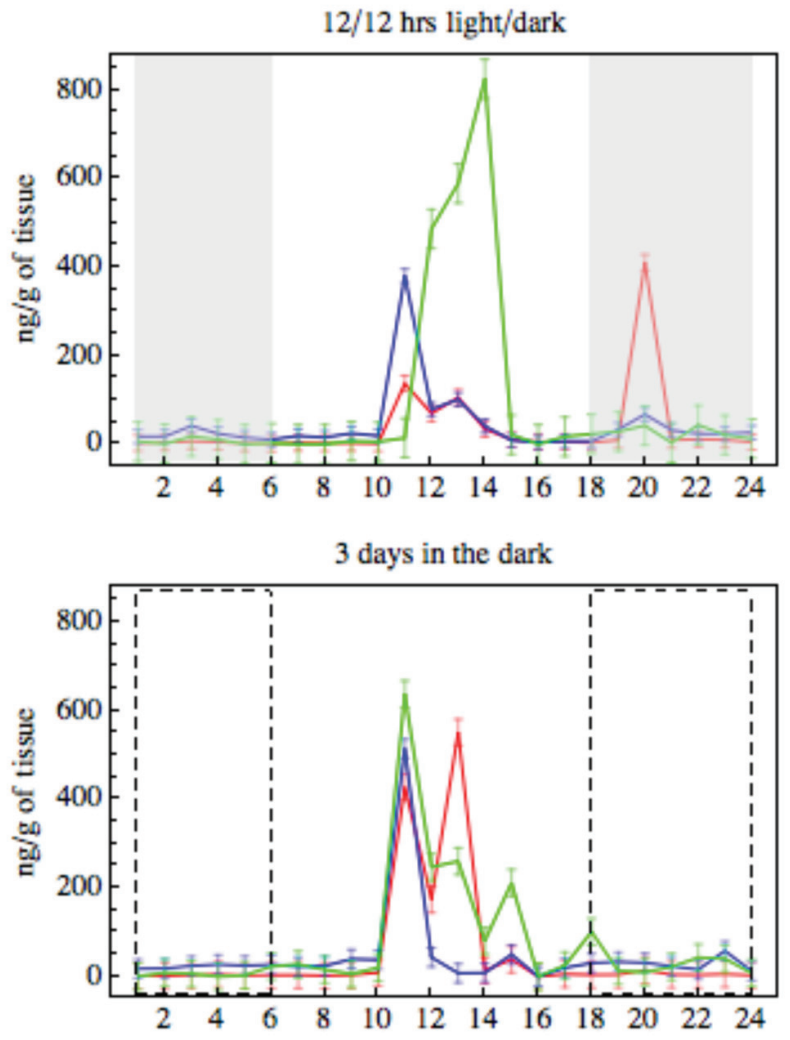

FIGURE 7 | Continued 
FIGURE 7 | (A) Cytoplasmic streaming Young leaf Chara cell showing the neutral zone between the two opposing cytoplasmic streams (black arrow), bar 500 $\mu \mathrm{m}$ (from Beilby and Casanova, 2013). (B) Model of cytoplasmic streaming (Shimmen, 2007): Chara myosin, which mediates the fast streaming speed, contacts actin via loop 3, with fast ADP release (most other myosins use loop 2, which slows ADP release). (C) Endogenous concentrations of auxin, melatonin and serotonin: changes over $24 \mathrm{~h}$ in IAA (green), melatonin (red) and serotonin (blue) in summer Chara thalli. Top graph: plants sampled straight from growth tank maintained on $12 / 12$ light/dark cycle, darkness is indicated by gray rectangles. Bottom graph: explants were pretreated 3 days in darkness, the dashed line rectangles indicate where plants experienced dark in the 12/12 h regime (adapted from Beilby et al., 2015).

is applied. Nothnagel et al. (1981) confirmed actin presence by fluorescently labeled phallotoxin, while Williamson and Toh (1979) used an antibody raised against actin. Williamson (1972) and Shimmen and Tazawa (1983) stopped streaming by applying the animal systems inhibitor of actin-based motility, cytochalasin.

In analogy to muscle movement it seemed likely that myosin also participates in cytoplasmic streaming. Kato and Tonomura (1977) purified myosin from Nitella. Chen and Kamiya (1975, 1981) located myosin in the cell by moving cytoplasm into one half of the cell by centrifugation. If the half without cytoplasm was treated by $\mathrm{SH}$ reagent $N$-ethylmaleimide (NEM), or heat of $47.5^{\circ} \mathrm{C}$, the subsequent streaming was not affected. When the same treatments were applied to cytoplasm-containing half of the cell, the streaming was disrupted in the whole cell. Therefore, similar to muscle, characean myosin is more sensitive to NEM and heat than actin and is found in the cytoplasm (for references see Shimmen and Yokota, 1994). Williamson (1975) observed cytoplasmic organelles, which became strongly bound to actin cables, when ATP was removed from perfusion medium in tonoplast free cells. Using electron microscopy Nagai and Hayama (1979) observed horn-like shapes with small globules ( $\sim 30 \mathrm{~nm}$ diameter) on endoplasmic organelles. Kachar and Reese (1988) agreed that myosin may be found in ER, to facilitate sliding along the actin cables.

In characean cells the streaming speed can reach $100 \mu \mathrm{m} / \mathrm{sec}$, much greater than that in higher plants and actin-myosin sliding in skeletal muscle. In "mix and match" experiments, glass was coated with myosin. The fluorescent-labeled actin filaments were added and their movement could be observed (Kron and Spudich, 1986). Shimmen and Yokota (1994) combined myosin from characean cytoplasm and actin filaments from skeletal muscle to observe similar sliding speeds to those in characean cytoplasmic streaming. Shimmen and Yano (1984) set up tonoplast-free cell with characean actin and perfused it with latex beads coated with skeletal muscle myosin. The slow velocity of this combination indicated that the speed of characean streaming is due to the native myosin.

Genetically characean myosin is similar to that of land plants: myosin XI. The myosin molecule was resolved by electron microscopy, showing two head structures and a tail that mediates the binding process (Shimmen, 2007, Figure 7B). While myosins in other species have positive charge on loop 2 and several lysine residues, Chara myosin loop 2 is uncharged with no lysine cluster. Instead, the loop 3 is positively charged (Ito et al., 2009), which leads to high ATPase activity. The less charge on loop 2 enables higher velocity. The structure of myosin, altered accordingly, speeded up the sliding in Dictyostelium.

\section{Energy Source: Adenylates and $\mathbf{M g}^{2+}$}

Williamson (1975) and Tazawa et al. (1976) determined that ATP provides energy for the myosin head to release. Without ATP the organelles are connected to actin cables by rigor cross-bridges (Nagai and Hayama, 1979). Shimmen (1978) found that maximum streaming velocity was reached at ATP concentrations above $200 \mu \mathrm{M}$, well above the normal cytoplasmic concentration of $0.5-3.4 \mathrm{mM}$. The relationship between streaming velocity and ATP concentration is linear. Consequently, inhibitors that diminish ATP concentration also affect streaming (Reid and Walker, 1983). Reid and Walker (1983), Shimmen (1988) perfused tonoplast-free cells with cytoplasm-like medium containing 1.6 ATP, 0.6 ADP, 0.8 AMP, $14.7 \mathrm{Pi}$ and 2 pyrophosphate (in $\mathrm{mM}$ ) and obtained normal streaming speeds. If only ADP was included in the perfusion medium, it was converted to ATP by adenylate kinase and streaming started after a delay. This streaming recovery was abolished by addition of adenylate kinase inhibitor to ADP medium. If the $\mathrm{Mg}^{2+}$ concentration in the perfusion medium was decreased compared to that of ATP, streaming speed declined (Shimmen, 1978, 1988). Shimmen and Tazawa (1983) confirmed the importance of $\mathrm{Mg}^{2+}$ by including $\mathrm{Mg}^{2+}$ chelator in the media, inhibiting streaming in both tonoplast-free and permeabilized experimental preparations. As in muscle $\mathrm{Mg}^{2+}$ is necessary for myosin ATPase reaction and it also maintains the streaming system.

\section{Temperature, $\mathrm{pH}$, Light and $\mathrm{Ca}^{2+}$}

Shimmen and Yoshida (1993) made detailed measurements of sensitivity of cytoplasmic streaming to temperature (for historical temperature measurements see references in Shimmen and Yokota, 1994). With $\mathrm{pH}$ and $\mathrm{Ca}^{2+}$ concentration controlled in perfused cells, there is a linear relationship between streaming velocity and temperature decrease in the range $25-0.5^{\circ} \mathrm{C}$. Some intact cells did show a steeper drop in streaming speed between 15 and $10^{\circ} \mathrm{C}$.

Fujii et al. (1979), Tazawa and Shimmen (1982) employed the tonoplast-free system to explore the effect of $\mathrm{pH}$, finding the greatest streaming velocity at neutral $\mathrm{pH}$. Shimmen and Tazawa (1985) investigated the effect of carboxylic acid secreted by leaf-cutting ant, myrmicacin. At low $\mathrm{pH}$, the undissociated form of the carboxylic acid penetrates the plasma membrane and acidifies the neutral cytoplasm by dissociation. Thus the cytoplasmic streaming is only affected if myrmicacin is applied at low external pH. Barr and Broyer (1964) reported higher velocity of streaming upon illumination, which was abolished by photosynthesis inhibitor DCMU (Plieth and Hansen, 1992). Miller and Sanders (1987) measured a decrease in cytoplasmic calcium concentration upon illumination, 
possibly due to $\mathrm{Ca}^{2+}$ uptake by the photosynthesising chloroplasts.

The early experiments researching the effects of $\mathrm{Ca}^{2+}$ on streaming were done on cytoplasmic droplets, which contained rotating chloroplasts (Hayama and Tazawa, 1980). The authors assumed that same actin-myosin mechanism was involved as in cytoplasmic streaming. Iontophoretic injection of different ions into the droplet produced different effect on the chloroplast movement: $\mathrm{K}^{+}$and $\mathrm{Mg}^{2+}$ had no effect, $\mathrm{Ca}^{2+}$ stopped the movement transiently, $\mathrm{Sr}^{2+}$ and $\mathrm{Ba}^{2+}$ had similar effect to $\mathrm{Ca}^{2+}$, $\mathrm{Mn}^{2+}$ and $\mathrm{Cd}^{2+}$ induced slow irreversible decline in motion. After Kikuyama and Tazawa (1982) stopped the streaming transiently by direct injection of $\mathrm{CaCl}_{2}$ into intact Nitella cell, Williamson (1975), Hayama et al. (1979) turned to tonoplastfree cells and found that up to $1 \mathrm{mM} \mathrm{Ca}^{2+}$ was needed to stop the streaming with incomplete recovery. Tominaga and Tazawa (1981) monitored streaming with time after perfusion and found that it became more sensitive to $\mathrm{Ca}^{2+}$ concentration. However, compared to intact cells the $\mathrm{Ca}^{2+}$ concentration for streaming stoppage was too high: the data from the perfused cells was misleading! Using aequorin Williamson and Ashley (1982) monitored the $\mathrm{Ca}^{2+}$ concentration in the cytoplasm of intact characean cells at the time of excitation: the peak concentration was $43 \mu \mathrm{M}$ in Nitella and only $6.7 \mu \mathrm{M}$ in Chara. At the time of AP, the streaming cytoplasm appears to "freeze" completely, restarting slowly after some minutes. Shimmen and Tazawa (1983) employed the permeabilized cells to confirm that only $1-10 \mu \mathrm{M} \mathrm{Ca}^{2+}$ were needed to stop the streaming. In the tonoplast-free system the native cytoplasm is removed in the perfusion process, while during permeabilization the cytoplasm is not disrupted. Consequently, it is a component of the cytoplasm that is $\mathrm{Ca}^{2+}$ sensitive.

Shimmen and Yano (1986) perfused cells with beads coated by skeletal muscle myosin and, like in the muscle; the movement dependence on calcium concentration was lost. Myosin in skeletal muscle has no $\mathrm{Ca}^{2+}$ sensitivity. Further, the incorporation of muscle troponin-tropomyosin complex into characean actin filaments actually made higher calcium concentration necessary to start streaming. Consequently, the calcium sensitivity in the intact characean cell is associated with myosin. As most of native cytoplasm is removed in rapidly perfused cells, the calcium sensitivity changed. In animal and mold systems myosin produces sliding either in phosphorylated or de-phosphorylated state. Tominaga et al. (1987) introduced phosphatase-1 into perfusion medium and abolished the streaming stoppage at high $\mathrm{Ca}^{2+}$ concentrations. The inhibitors of phosphatase-1, on the other hand, totally inhibited streaming. As characean myosin only promotes streaming in de-phosphorylated state, ATP- $\gamma$-S irreversibly inhibited the recovery of streaming after it was stopped by high $\mathrm{Ca}^{2+}$ concentration (thio-phosphorylated proteins are not de-phophorylated with phosphatases). The authors suggest that at the time of an AP the phosphatase is activated indirectly through $\mathrm{Ca}^{2+}$ binding to calmodulin, as $\mathrm{Ca}^{2+}$ concentration rises. Calmodulin inhibitors, indeed, prevent streaming recovery only following exposure to high $\mathrm{Ca}^{2+}$ concentration, while steady state streaming is not affected (Tominaga et al., 1985).

\section{The Importance of Streaming}

Cytoplasmic streaming can be observed in many eukaryotic organisms: algae, higher plants, fungi, slime molds, nematodes and flies. The cells that utilize cytoplasmic streaming tend to be larger than the usual $10-100 \mu \mathrm{m}$ or have specialized functions (Goldstein and van de Meent, 2015). However, some cells of normal size, such as cells in stinging nettle, parenchymal cells in onion or leaf cells in Elodea, exhibit slow circulation streaming. Fountain streaming can be observed in root hairs and pollen tubes of various higher plants. The details of the actin-myosin driven streaming were elucidated in characean cells, because their cell compartments can be manipulated. In large celled characean thalli streaming is crucial for intercellular transport of both nutrients and organic compounds (see Radioactive or Substitution Tracers). The $\mathrm{pH}$ banding that aids carbon fixation does not occur without streaming. There may be further roles of streaming in cell metabolism and improving homeostasis by enhancing vacuolar mixing (Goldstein and van de Meent, 2015).

\section{Evolution of Hormone Auxin and its Signaling Pathways \\ Polar Auxin Transport (PAT)}

In land plants growth and development is directed by auxin indole-3-acetic acid (IAA) concentration minima, maxima and gradients. Young shoots of land plants produce IAA and transport it to roots by parenchyma cells which produce auxin influx- (AUX, LAX) and efflux- (PIN) supporting proteins (for review see Petrasek and Friml, 2009). 1-N-naphthylphthalamic acid (NPA) is an efficient inhibitor of the efflux PIN proteins. IAA research in Characeae can elucidate some of the developmental steps in auxin signaling and metabolic pathways from origins in chlorophyte algae (De Smet et al., 2011) to the complexity of extant land plants.

Hori et al. (2014) detected auxin in the basal branching charophyte Klebsormidium. In Characeae with more complex morphology, effects of external IAA and its transport through the thallus and rhizoids were investigated. Klambt et al. (1992) observed rhizoids developing in cuttings of Chara globularis. The polar growth of rhizoids was inhibited by explant decapitation or by addition of NPA. If IAA was added to the medium, the inhibition of growth was reversed. ${ }^{14} \mathrm{C}$ IAA was retained by the explants more strongly after treatment with NPA. Thus NPA seems to inhibit IAA efflux as it does in higher plants. The rhizoid development in mosses is also affected by IAA (Eklund et al., 2010). Clabeaux and Bisson (2009) decapitated C. australis explants or tied the second internode with a silk thread to prevent basipetal transport through streaming. Greater number of axillary branches was observed in decapitated explants and below the tied thread: clear demonstration of apical dominance. However, unlike higher plants, the tied explants also produced greater number of rhizoids and addition of IAA to the medium had no effect.

Boot et al. (2012) placed one or two adjacent internodes of C. corallina in three-compartment chamber. The middle chamber was labeled by addition of ${ }^{3} \mathrm{H}$-IAA and the appearance of the label was then monitored in the outer chambers. After $1 \mathrm{hr}$ 
the shoot to rhizoid directed transport of IAA was 50-times greater than that in the opposite direction. The polarity was lost upon exposure to NPA. Initially, the IAA transport through the thallus was attributed to cytoplasmic streaming, as the rate was comparable. When no rate decrease resulted from streaming inhibition by cytochalasin, Raven (2013) proposed involvement of other mechano-chemical motors such as dynein-tubulin or kinesin-tubulin. If the label was added to one of the outer compartments, large amount of IAA was detected in the middle compartment. The cortication of C. vulgaris prevented some of the leakage. The authors concluded that the auxin influx carrier proteins of higher plants are probably lacking in Characeae. Bennett et al. (2014) made a detailed study of PIN protein evolution, finding that charophyte Klebsormidium PIN structure was substantially different to that of higher plants. Thus the IAA transport proteins evolved to their present forms in different types of tissues of land plants.

\section{Circadian and Seasonal Effects on IAA and Melatonin/Serotonin Metabolic Pathways}

Beilby et al. (2015) measured circadian concentrations of IAA, melatonin and serotonin in C. australis plants. The plants, which experienced summer day-length and temperatures, exhibited distinct concentration maxima about $4 \mathrm{~h}$ after subjective daybreak. Similar concentration distribution persisted in plants pre-treated for 3 days in the dark, confirming a circadian rhythm (Figure 7C). Plants pre-treated 3 days in the light exhibited more IAA concentration maxima, while melatonin and serotonin exhibited smaller concentrations changes, less synchronized with those of IAA. In the winter plants exhibited much smaller IAA concentration maxima in the subjective dark phase, which again persisted after dark pre-treatment. Melatonin and serotonin concentrations were also much smaller, compared to summer cells, with only a weak correlation to IAA concentration changes. The close synchronization between IAA and serotonin circadian cycling suggests IAA biosynthesis by the tryptamine pathway, which intersects with the serotonin/melatonin pathway (Mano and Nemoto, 2012; Ljung, 2013). The IAA synthesis was recently investigated in charophytes by searching for sequences of tryptophan aminotransferase (TAA) and flavin monooxygenase (YUCCA) enzymes that mediate the main synthesis pathway in model plant Arabidopsis. Wang et al. (2014) found homologs of

\section{REFERENCES}

Barbier-Brygoo, H., Vinauger, M., Colcombet, J., Ephritikhine, G., Frachisse, J.-M., and Maurel, C. (2000). Anion channels in higher plants: functional characterization, molecular structure and physiological role. Biochim. Biophys. Acta 1465, 199-218. doi: 10.1016/S0005-2736(00)00139-5

Barr, C. E., and Broyer, T. (1964). Effect of light on sodium influx, membrane potential, and protoplasmic streaming in Nitella. Plant Physiol. 39, 48-52. doi: 10.1104/pp.39.1.48

Beilby, M. J. (1985). Potassium channels at Chara plasmalemma. J. Exp. Bot. 36, 228-239. doi: 10.1093/jxb/36.2.228

Beilby, M. J. (1989). "Electrophysiology of giant algal cells," Methods in Enzymology, Vol. 174, eds S. Fleischer and B. Fleischer (San Diego, CA: Academic Press), 403-443. these enzymes in Klebsormidium and two Characeae, but Turnaev et al. (2015) argued that the differences are too large for the enzymes to be functional. Ke et al. (2015) suggested that the results are inconclusive. So, this is clearly a very active research area!

The data in this section indicate that polar auxin transport and circadian influence on IAA pre-dates emergence of plants on land. The advantage of using characean thalli for biochemical assays are (i) small number of large internodal cells (with their contents dominating over much smaller nodal complexes) in each sample and (ii) relatively small differentiation between axial and leaf internodes compared to variety of tissues encountered in vascular land plants. The seasonal and circadian nature of endogenous IAA concentration also highlights the importance of collecting plant samples in the right season and at the right part of day cycle.

\section{CONCLUSION}

The size of characean cells provides the experimentalist with many options not available in typical plant cells or tissue. Due to this unusual morphology, Characeae were initially regarded as "interesting," but not representative of higher plants. In recent decades, however, many higher plant-like properties are starting to emerge. The different aspects of the Characeae research are now coming together: electrophysiology, nutrient acquisition, cell to cell transport, carbon concentrating mechanisms, cytoplasmic streaming, geotropism, metabolic pathways, circadian rhythms, plant evolution, wound healing, cytoskeleton organization, cell walls, phytoremediation, lake ecology - too many topics to be discussed in this review. On the other hand, the exceptional Characeae morphology is providing insights into physical limits of cell size, transport of nutrients, homeostasis and macromolecular targeting (Goldstein and van de Meent, 2015). The Characeae system is about to become even more valuable with sequencing of $C$. braunii.

\section{AUTHOR CONTRIBUTIONS}

The author confirms being the sole contributor of this work and approved it for publication.

Beilby, M. J. (2015). Salt tolerance at single cell level in giant-celled Characeae. Front. Plant Sci. 6:226. doi: 10.3389/fpls.2015.00226

Beilby, M. J., and Bisson, M. A. (2012). "pH banding in charophyte algae," in Plant Electrophysiology, Chap. 11, ed. A. Volkov (Berlin: Springer-Verlag), 247-271.

Beilby, M. J., and Casanova, M. T. (2013). The Physiology of Characean Cells. Berlin: Springer.

Beilby, M. J., Cherry, C. A., and Shepherd, V. A. (1999). Dual regulation response to hypertonic stress in Lamprothaminum papulosum. Plant Cell Environ. 22, 347-359. doi: 10.1046/j.1365-3040.1999.00406.x

Beilby, M. J., Turi, C. E., Baker, T. C., Tymm, F. J. M., and Murch, S. J. (2015). Circadian changes in endogenous concentrations of indole-3-acetic acid, melatonin, serotonin, abscisic acid and jasmonic acid in Characeae (Chara australis Brown). Plant Signal. Behav. 10:e1082697. doi: 10.1080/15592324. 2015.1082697 
Beilby, M. J., and Walker, N. A. (1981). Chloride transport in Chara: I. kinetics and current-voltage curves for a probable proton symport. J. Exp. Bot. 32, 43-54. doi: $10.1093 / \mathrm{jxb} / 32.1 .43$

Berecki, G., Eijken, M., Van Iren, F., and Van Duijn, B. (2001). Tonoplast anion channel activity modulation by $\mathrm{pH}$ in Chara corallina. J. Membr. Biol. 184, 131-141. doi: 10.1007/s00232-001-0081-6

Berecki, G., Varga, Z., Van Iren, F., and Van Duijn, B. (1999). Anion channels in Chara corallina tonoplast membrane: calcium dependence and rectfication. J. Membr. Biol. 172, 159-168. doi: 10.1007/s002329900593

Bertl, A. (1989). Current-voltage relationships of sodium-sensitive potassium channel in the tonoplast of Chara corallina. J. Membr. Biol. 109, 9-19. doi: 10.1007/BF01870786

Bennett, T. A., Liu, M. M., Aoyama, T., Bierfreund, N. M., Braun, M., Coudert, Y., et al. (2014). Plasma membrane-targeted PIN proteins drive shoot development in a moss. Curr. Biol. 24, 2776-2785 doi: 10.1016/j.cub.2014.09.054

Beyenbach, K. W., and Wieczorek, H. (2006). The V-type $\mathrm{H}^{+}$ATPase: molecular structure and function, physiological roles and regulation. J. Exp. Biol. 209, 577-589. doi: 10.1242/jeb.02014

Bisson, M. A., and Kirst, G. O. (1980). Lamprothamnium, a euryhaline charophyte II. Time course of turgor regulation. J. Exp. Bot. 31, 1237-1244. doi: $10.1093 / \mathrm{jxb} / 31.5 .1237$

Blatt, M. R., Wang, Y., Leonhardt, N., and Hills, A. (2014). Exploring emergent properties in cellular homeostasis using OnGuard to model $\mathrm{K}^{+}$ and other ion transport in guard cells. J. Plant Physiol. 171, 770-778. doi: 10.1016/j.jplph.2013.09.014

Boot, K., Libbenga, K. R., Hille, S. C., Offringa, R., and van Duijn, B. (2012). Polar auxin transport: an early invention. J. Exp. Bot. 63, 4213-4218. doi: $10.1093 /$ jxb/ers106

Bostrom, T. E., and Walker, N. A. (1975). Intercellular transport in plants. I. The rate of transport of chloride and the electric resistance. J. Exp. Bot. 26, 767-782. doi: $10.1093 / \mathrm{jxb} / 26.6 .767$

Bostrom, T. E., and Walker, N. A. (1976). Intercellular transport in plants. II. Cyclosis and the rate of intercellular transport of chloride in Chara. J. Exp. Bot. 27, 347-357. doi: 10.1093/jxb/27.2.347

Box, R., Andrews, M., and Raven, J. A. (1984). Intercellular transport and cytoplasmic streaming in Chara hispida. J. Exp. Bot. 35, 1016-1021. doi: $10.1093 / j x b / 35.7 .1016$

Brecknock, S., Dibbayawan, T. P., Vesk, M., Vesk, P. A., Faulkner, C., Barton, D. A., et al. (2011). High resolution scanning electron microscopy of plasmodesmata. Planta 234, 749-758. doi: 10.1007/s00425-011-1440-x

Burch-Smith, T., and Zambryski, P. (2012). Plasmodesmata paradigm shift: regulation from without versus within. Annu. Rev. Plant Biol. 63, 239-260. doi: 10.1146/annurev-arplant-042811-105453

Chen, J., and Kamiya, N. (1975). Localisation of myosin in the internodal cell of Nitella as suggested by differential treatment with N-ethylmaleimide. Cell Struct. Funct. 1, 1-9. doi: 10.1247/csf.1.1

Chen, J., and Kamiya, N. (1981). Differential heat treatment of the Nitella internodal cell and its relation to cytoplasmic streaming. Cell Struct. Funct. 6, 201-207. doi: 10.1247/csf.6.201

Clabeaux, B. L., and Bisson, M. A. (2009). Developmental patterns in Chara australis (Characeae, Charophyceae): apical dominance, $\mathrm{pH}$ and auxin. Charophytes 1, 68-72.

Cook, M. E., Graham, L. E., Botha, C. E. J., and Lavin, C. A. (1997). Comparative ultrastructure of plasmodesmata of Chara and selected bryophytes: toward an elucidation of the evolutionary origin of plant plasmodesmata. Am. J. Bot. 84, 1169-1178. doi: $10.2307 / 2446040$

Cote, R., Thain, J. F., and Fenson, D. S. (1987). Increase in electrical resistance of plasmodesmata of Chara induced by an applied pressure gradient across nodes. Can. J. Bot. 65, 509-511. doi: 10.1139/b87-064

De Smet, I., Voss, U., Lau, S., Wilson, M., Shao, N., Timme, R. E., et al. (2011). Unravelling the evolution of auxin signalling. Plant Physiol. 155, 209-221. doi: 10.1104/pp.110.168161

de Vries, J., Stanton, A., Archibald, J. M., and Gould, S. B. (2016). Streptophyte terrestrialization in light of plastid evolution. Trends Plant Sci. 21, 467-476. doi: 10.1016/j.tplants.2016.01.021

Ding, D., and Tazawa, M. (1989). Influence of cytoplasmic streaming and turgor pressure gradient on the transnodal transport of rubidium and electrical conductance in Chara corallina. Plant Cell Physiol. 30, 739-748.
Ding, D. Q., Amino, S., Mimura, T., Sakano, K., Nagata, T., and Tazawa, M. (1992). Quantitative analysis of intercellularly transported photoassimilates in Chara corallina. J. Exp. Bot. 43, 1045-1051. doi: 10.1093/jxb/43.8. 1045

Draber, S., Schultze, R., and Hansen, U.-P. (1993). Cooperative behaviour of $\mathrm{K}^{+}$ channels in the tonoplast of Chara corallina. Biophys. J. 65, 1553-1559. doi: 10.1016/S0006-3495(93)81194-9

Eklund, D. M., Thelander, M., Landberg, K., Ståldal, V., Nilsson, A., Johansson, M., et al. (2010). Homologues of the Arabidopsis thaliana SHI/STY/LRP1 genes control auxin biosynthesis and affect growth and development in the moss Physcomitrella patens. Development 137, 1275-1284. doi: 10.1242/dev. 039594

Evkaikina, A. I., Romanova, M. A., and Voitsekhovskaja, O. V. (2014). Evolutionary aspects of non-cell-autonomous regulation in vascular plants: structural background and models to study. Front. Plant Sci. 5:31. doi: 10.3389/fpls.2014.00031

Fairley, K. A., and Walker, N. A. (1987). Amine ion porter in Chara australis: effects of alkyl substitution and external pH. J. Membr. Biol. 98, 191-196. doi: 10.1007/BF01872130

Felle, H. H. (1994). The $\mathrm{H}^{+} / \mathrm{Cl}^{-}$symporter in root-hair cells of Sinapis alba. An electrophysiological study using ion-selective microelectrodes. Plant Physiol. $106,1131-1136$.

Findlay, G. P., Hope, A. B., Pitman, M. G., Smith, F. A., and Walker, N. A. (1969). Ion fluxes in cells of Chara corallina. Biochim. Biophys. Acta 183, 565-576. doi: 10.1016/0005-2736(69)90170-9

Franceschi, V. R., Ding, B., and Lucas, W. J. (1994). Mechanism of plasmodesmata formation in characean algae in relation to evolution of intercellular communication in higher plants. Planta 192, 347-358. doi: 10.1007/BF00198570

Fujii, S., Shimmen, T., and Tazawa, M. (1979). Effect of intracellular pH on the light-induced potential change and electrogenic activity in tonoplast-free cells of Chara australis. Plant Cell Physiol. 20, 1315-1328.

Goldstein, R. E., and van de Meent, J.-W. (2015). A physical perspective on cytoplasmic streaming. Interface Focus 5:20150030. doi: 10.1098/rsfs.2015.0030

Hayama, T., Shimmen, T., and Tazawa, M. (1979). Participation of $\mathrm{Ca}^{2+}$ in cessation of cytoplasmic streaming induced by membrane excitation in Characeae internodal cells. Protoplasma 99, 305-321. doi: 10.1007/BF012 75803

Hayama, T., and Tazawa, M. (1980). $\mathrm{Ca}^{2+}$ reversibly inhibits active rotation of chloroplasts in isolated cytoplasmic droplets of Chara. Protoplasma 102, 1-9. doi: 10.1007/BF01276943

Hedrich, R. (2012). Ion channels in plants. Physiol. Rev. 92, 1777-1811. doi: 10.1152/physrev.00038.2011

Hedrich, R., and Schroeder, J. I. (1989). The physiology of ion channels and electrogenic pumps in higher plants. Annu. Rev. Plant Physiol. 40, 539-569. doi: 10.1146/annurev.pp.40.060189.002543

Homble, F., and Fuks, B. (1991). Quantitative analysis of single $\mathrm{K}^{+}$channels in the tonoplast of Chara corallina: selectivity and TEA blockade. J. Plant Physiol. 137, 729-733. doi: 10.1016/S0176-1617(11)81230-7

Hope, A. B., and Walker, N. A. (1975). The Physiology of Giant Algal Cells. London: Cambridge University Press.

Hori, K., Maruyama, F., Fujisawa, T., Togashi, T., Yamamoto, N., Seo, M., et al. (2014). Klebsormidium flaccidum genome reveals primary factors for plant terrestrial adaptation. Nat. Commun. 5:3978. doi: 10.1038/ncomms 4978

Ito, K., Yamaguchi, Y., Yanase, K., Ichikawa, Y., and Yamamoto, K. (2009). Unique charge distribution in surface loops confers high velocity on the fast motor protein Chara myosin. Proc. Natl. Acad. Sci. U.S.A. 106, 21585-21590. doi: 10.1073/pnas.0910787106

Kachar, B., and Reese, T. (1988). The mechanism of cytoplasmic streaming in characeaen algal cells: sliding of endoplasmic reticulum along actin filaments. J. Cell Biol. 106, 1545-1552. doi: 10.1083/jcb.106.5.1545

Kamitsubo, E. (1966). Motile protoplasmic fibrils in cells of Characeae. II. Linear fibrillar structure and its bearing on protoplasmic streaming. Proc. Jpn. Acad. $42,640-643$.

Kamitsubo, E. (1972). A "window technique" for detailed observation of characean cytoplasmic streaming. Exp. Cell Res. 74, 613-616. doi: 10.1016/00144827(72)90430-2 
Kamiya, N., and Kuroda, K. (1956). Velocity distribution of the protoplasmic streaming in Nitella cells. Bot. Magazine (Tokyo) 69, 544-554. doi: 10.15281/jplantres1887.69.544

Karol, K. G., McCourt, R. M., Cimino, M. T., and Delwiche, C. F. (2001). The closest living relatives of land plants. Science 294, 2351-2353. doi: 10.1126/science. 1065156

Kato, T., and Tonomura, Y. (1977). Identification of myosin in Nitella flexilis. J. Biochem. 82, 777-782.

Katsuhara, M., Mimura, T., and Tazawa, M. (1989). Patch-clamp study on a $\mathrm{Ca}^{2+}$-regulated $\mathrm{K}^{+}$channel in the tonoplast of the brackish characeae Lamprothamnium succinctum. Plant Cell Physiol. 30, 549-555.

Ke, M., Zheng, Y., and Zhu, Z. (2015). Rethinking the origin of auxin biosynthesis in plants. Front. Plant Sci. 6:1093. doi: 10.3389/fpls.2015.01093

Kersey, Y., and Wessells, N. (1976). Localisation of actin filaments in internodal cells of characean algae. J. Cell Biol. 68, 264-275. doi: 10.1083/jcb.68.2.264

Kikuyama, M., and Tazawa, M. (1982). $\mathrm{Ca}^{2+}$ ion reversibly inhibits the cytoplasmic streaming of Nitella. Protoplasma 113, 241-243. doi: 10.1007/BF01280914

Klambt, D., Knauth, B., and Dittmann, I. (1992). Auxin dependent growth of rhizoids of Chara globularis. Physiol. Plant. 85, 537-540. doi: 10.1111/j.13993054.1992.tb05823.x

Koselski, M., Trebacz, K., and Dziubinska, H. (2013). Cation-permeable vacuolar ion channels in the moss Physcomitrella patens: a patch-clamp study. Planta 238, 357-367. doi: 10.1007/s00425-013-1902-4

Kron, S., and Spudich, J. (1986). Fluorescent actin filaments move on myoscin fixed to a glass surface. Proc. Natl. Acad. Sci. U.S.A. 83, 6272-6276. doi: 10.1073/pnas.83.17.6272

Kwiatkowska, M. (2003). Plasmodesmal changes are related to different developmental stages of antheridia of Chara species. Protoplasma 222, 1-11. doi: 10.1007/s00709-003-0001-y

Laver, D. R. (1992). Divalent cation block and competition between divalent and monovalent cations in the large-conductance $\mathrm{K}^{+}$channel from Chara australis. J. Gen. Physiol. 100, 269-300. doi: 10.1085/jgp.100.2.269

Laver, D. R., Cherry, C. A., and Walker, N. A. (1997). The actions of calmodulin antagonists W-7 and TFP and of calcium on the gating kinetics of the calcium-activated large conductance potassium channel of the Chara protoplasmic drop: a substate-sensitive analysis. J. Membr. Biol. 155, 263-274. doi: $10.1007 / \mathrm{s} 002329900179$

Laver, D. R., Fairley, K. A., and Walker, N. A. (1989). Ion permeation in a $\mathrm{K}^{+}$ channel in Chara australis: direct evidence for diffusion limitation of ion flow in a maxi-K channel. J. Membr. Biol. 108, 153-164. doi: 10.1007/BF01871026

Laver, D. R., and Walker, N. A. (1987). Steady-state voltage-dependent gating and conduction kinetics of single $\mathrm{K}^{+}$channels in the membrane of cytoplasmic drops of Chara australis. J. Membr. Biol. 100, 31-42. doi: 10.1007/BF022 09138

Laver, D. R., and Walker, N. A. (1991). Activation by $\mathrm{Ca}^{2+}$ and block by divalent ions of the $\mathrm{K}^{+}$channel in the membrane of cytoplasmic drops from Chara australis. J. Membr. Biol. 120, 131-139. doi: 10.1007/BF01872396

Ljung, K. (2013). Auxin metabolism and homeostasis during plant development. Development 140, 943-950. doi: 10.1242/dev.086363

Ludewig, U., Neuhauser, B., and Dynowski, M. (2007). Molecular mechanisms of ammonium transport and accumulation in plants. FEBS Lett. 581, 2301-2308. doi: 10.1016/j.febslet.2007.03.034

Luhring, H. (1986). Recording of single $\mathrm{K}^{+}$channels in the membrane of cytoplasmic drop of Chara australis. Protoplasma 133, 19-27. doi: 10.1007/BF01293183

Maathuis, F. J. M., Verlin, D., Smith, F. A., Sanders, D., Fernandez, J. A., and Walker, N. A. (1996). The physiological relevance of $\mathrm{Na}^{+}$-coupled $\mathrm{K}^{+}$transport. Plant Physiol. 112, 1609-1616.

MacRobbie, E. A. C. (1969). Ion fluxes to the vacuole of Nitella translucens. J. Exp. Bot. 20, 236-256. doi: 10.1093/jxb/20.2.236

MacRobbie, E. A. C. (1975). Intracellular kinetics of tracer chloride and bromide in Nitella translucens. J. Exp. Bot. 26, 489-507. doi: 10.1093/jxb/26.4.489

Mano, Y., and Nemoto, K. (2012). The pathway of auxin biosynthesis in plants. J. Exp. Bot. 63, 2853-2872. doi: 10.1093/jxb/ers091

Martinoia, E., Maeshima, M., and Neuhaus, H. E. (2007). Vacuolar transporters and their essential role in plant metabolism. J. Exp. Bot. 58, 83-102. doi: $10.1093 / \mathrm{jxb} / \mathrm{erl} 183$
McCulloch, S., Beilby, M. J., and Walker, N. A. (1990). Transport of potassium in Chara australis: II. Kinetics of a symport with sodium. J. Membr. Biol. 115, 129-143. doi: 10.1007/BF01869452

McDonald, T. R., Dietrich, F. S., and Lutzoni, F. (2011). Multiple horizontal gene transfers of ammonium transporters/ammonia permeases from prokaryotes to eukaryotes: toward a new functional and evolutionary classification. Mol. Biol. Evol. 29, 51-60. doi: 10.1093/molbev/msr123

Miller, A. J., and Sanders, D. (1987). Depletion of cytosolic calcium induced by photosynthesis. Nature (Lond.) 326, 397-400.

Mimura, T. (1999). Regulation of phosphate transport and homeostasis in plant cells. Int. Rev. Cytol. 191, 149-200. doi: 10.1016/S0074-7696(08)60159-X

Mimura, T. (2001). Physiological control of phosphate uptake and phosphate homeostasis in plant cells. Aust. J. Plant Physiol. 28, 655-660.

Mimura, T., Reid, R. J., Ohsumi, Y., and Smith, F. A. (2002). Induction of the $\mathrm{Na}^{+} / \mathrm{Pi}$ cotransport system in the plasma membrane of Chara corallina requires external $\mathrm{Na}^{+}$and low levels of Pi. Plant Cell Environ. 25, 1475-1481. doi: 10.1046/j.1365-3040.2002.00921.x

Mimura, T., Reid, R. J., and Smith, F. A. (1998). Control of phosphate transport across the plasma membrane of Chara corallina. J. Exp. Bot. 49, 13-19. doi: $10.1093 / \mathrm{jxb} / 49.318 .13$

Moriyasu, Y., Shimmen, T., and Tazawa, M. (1984a). Vacuolar pH regulation in Chara australis. Cell Struct. Funct. 9, 225-234. doi: 10.1247/csf.9.235

Moriyasu, Y., Shimmen, T., and Tazawa, M. (1984b). Electric characteristics of the vacuolar membrane of Chara in relation to $\mathrm{pHv}$ regulation. Cell Struct. Funct. 9, 235-246. doi: 10.1247/csf.9.235

Nagai, R., and Hayama, T. (1979). Ultrastructure of the endoplasmic factor responsible for cytoplasmic streaming in Chara internodal cells. J. Cell Sci. 36, $121-136$.

Nagai, R., and Rebhun, L. (1966). Cytoplasmic microfilaments in streaming Nitella cells. J. Ultrastruct. Res. 14, 571-589. doi: 10.1016/S0022-5320(66)80083-7

Nakanishi, Y., Matsuda, N., Aizawa, K., Kashiyama, T., Yamamoto, K., Mimura, T., et al. (1999). Molecular cloning and sequencing of the cDNA for vacuolar $\mathrm{H}^{+}$pyrophosphatase from Chara corallina. Biochim. Biophys. Acta 1418, 245-250. doi: 10.1016/S0005-2736(99)00037-1

Nothnagel, E., Barak, L. S., Sanger, J. W., and Webb, W. W. (1981). Fluorescence studies on modes of cytochalasin and phallotoxin action on cytoplasmic streaming in Chara. J. Cell Biol. 88, 364-372. doi: 10.1083/jcb.88.2.364

Nussaume, N., Kanno, S., Javot, H., Marin, E., Pochon, N., Ayadi, A., et al. (2011). Phosphate import in plants: focus on the PHT1 transporters. Front. Plant Sci. 2:83. doi: 10.3389/fpls.2011.00083

Oparka, K. J., and Prior, D. A. M. (1992). Direct evidence for pressuregenerated closure of plasmodesmata. Plant J. 2, 741-750. doi: 10.1111/j.1365313X.1992.tb00143.x

Palevitz, B., Ash, J. F., and Hepler, P. K. (1974). Actin in the green alga, Nitella. Proc. Natl. Acad. Sci. U.S.A. 71, 363-366. doi: 10.1073/pnas.71.2.363

Pantoja, O. (2012). High affinity ammonium transporters: molecular mechanism of action. Front. Plant Sci. 3:34. doi: 10.3389/fpls.2012.00034

Petrasek, J., and Friml, J. (2009). Auxin transport routes in plant development. Development 136, 2675-2688. doi: 10.1242/dev.030353

Plieth, C., and Hansen, U.-P. (1992). Light dependence of protoplasmic streaming in Nitella flexilis L. as measured by means of laser-velocimetry. Plant 188, 332-339. doi: 10.1007/BF00192799

Pottosin, I., and Andjus, P. R. (1994). Depolarization-zctivated $\mathrm{K}^{+}$channel in Chara droplets. Plant Physiol. 106, 313-319.

Raven, J. A. (2005). "Evolution of plasmodesmata," in Annual Plant Reviews, Plasmodesmata, Vol. 18, ed. K. J. Oparka (Hoboken: Wiley-Blackwell), 33-53.

Raven, J. A. (2013). Polar auxin transport in relation to long-distance transport of nutrients in the Charales. J. Exp. Bot. 64, 1-9. doi: 10.1093/jxb/ers358

Rea, P. A., and Sanders, D. (1987). Tonoplast energization: two $\mathrm{H}^{+}$pumps, one membrane. Physiol. Plant. 71, 131-141. doi: 10.1111/j.1399-3054. 1987.tb04630.x

Reid, R. J., Mimura, T., Ohsumi, Y., Walker, N. A., and Smith, F. A. (2000). Phosphate uptake in Chara: membrane transport via Na/Pi cotransport. Plant Cell Environ. 23, 223-228. doi: 10.1046/j.1365-3040.2000.00524.x

Reid, R. J., and Overall, R. L. (1992). Intercellular communication in Chara: factors affecting transnodal electrical resistance and solute fluxes. Plant Cell Environ. 15, 507-517. doi: 10.1111/j.1365-3040.1992.tb01484.x 
Reid, R. J., and Walker, N. A. (1983). Adenylate concentrations in Chara: variability, effects of inhibitors and relationship to protoplasmic streaming. Aust. J. Plant Physiol. 10, 373-383.

Ritchie, R. J. (1987). The permeability of ammonia, methylamine and ethylamine in charophyte Chara corallina (C. australis). J. Exp. Bot. 38, 67-76. doi: $10.1093 / \mathrm{jxb} / 38.1 .67$

Ritchie, R. J., Trautman, D. A., and Larkum, A. W. D. (1997). Phosphate uptake in the cyanobacterium Synechococcus R-2 (Anacystis nidulans, S. leopoliensis) PCC 7942. Plant Cell Physiol. 38, 1232-1241. doi: 10.1093/oxfordjournals.pcp.a029110

Ruhfel, B. R., Gitzendanner, M. A., Soltis, P. S., Soltis, D. E., and Burleigh, J. G. (2014). From algae to angiosperms - inferring the phylogeny of green plants (Viridiplantae) from 360 plastid genomes. BMC Evol. Biol. 14:23. doi: 10.1186/1471-2148-14-23

Ryan, P. R., and Walker, N. A. (1993). Malate accumulates in the vacuole of Chara australis during uptake of ammonium from chloride-free solution. J. Exp. Bot. 44, 637-643. doi: 10.1093/jxb/44.3.637

Ryan, P. R., and Walker, N. A. (1994). The regulation of ammonia uptake in Chara australis. J. Exp. Bot. 45, 1057-1067. doi: 10.1093/jxb/45.8.1057

Sakano, K., and Tazawa, M. (1986). Tonoplast origin of the envelope membrane of cytoplasmic droplets prepared from Chara internodal cells. Protoplasma 131, 247-249. doi: 10.1007/BF01282988

Sanders, D. (1980a). Control of $\mathrm{Cl}$ influx in Chara by cytoplasmic $\mathrm{Cl}^{-}$ concentration. J. Membr. Biol. 52, 51-60. doi: 10.1007/BF01869005

Sanders, D. (1980b). The mechanism of $\mathrm{Cl}^{-}$transport at the plasma membrane of Chara corallina I. Cotransport with $\mathrm{H}^{+}$. J. Membr. Biol. 53, 129-141. doi: 10.1007/BF01870581

Sanders, D., and Hansen, U. P. (1981). Mechanism of $\mathrm{Cl}^{-}$transport at the plasma membrane of Chara corallina: II. Transhibition and the determination of $\mathrm{H}^{+} / \mathrm{Cl}^{-}$binding order from a reaction kinetic model. J. Membr. Biol. 58, 139-153. doi: 10.1007/BF01870976

Schultze, R., and Draber, S. (1993). A nonlinear filter algorithm for the detection of jumps in patch-clamp data. J. Membr. Biol. 132, 41-52. doi: 10.1007/BF00233050

Shepherd, V. A., and Goodwin, P. B. (1992a). Seasonal patterns of cellto-cell communication in Chara corallina Klein ex Willd. I. Cell-to-cell communication in vegetative lateral branches during winter and spring. Plant Cell Environ. 15, 137-150. doi: 10.1111/j.1365-3040.1992.tb01468.x

Shepherd, V. A., and Goodwin, P. B. (1992b). Seasonal patterns of cellto-cell communication in Chara corallina Klein ex Willd. II. Cell-to cell communication during the development of antheridia. Plant Cell Environ. 15, 151-162. doi: 10.1111/j.1365-3040.1992.tb01468.x

Shimmen, T. (1978). Dependency of cytoplasmic streaming on intracellular ATP and $\mathrm{Mg}^{2+}$ concentrations. Cell Struct. Funct. 3, 113-121. doi: 10.1247/csf. 3.113

Shimmen, T. (1988). Cytoplasmic streaming regulated by adenine nucleotides and inorganic phosphates in Characeae. Protoplasma Suppl. 1, 3-9. doi: 10.1007/978-3-7091-9008-1_1

Shimmen, T. (2007). The sliding theory of cytoplasmic streaming: fifty years of progress. J. Plant Res. 120, 31-43. doi: 10.1007/s10265-006-0061-0

Shimmen, T., and MacRobbie, E. A. C. (1987). Characterisation of two proton transport systems in the tonoplast of plasmalemma-permeabilized Nitella cells. Plant Cell Physiol. 28, 1023-1031.

Shimmen, T., and Tazawa, M. (1982). Reconstitution of cytoplasmic streaming in Characeae. Protoplasma 113, 127-131. doi: 10.1007/BF01282001

Shimmen, T., and Tazawa, M. (1983). Control of cytoplasmic streaming by ATP, $\mathrm{Mg}^{2+}$ and cytochalasin B in permeabilized Characeae cell. Protoplasma 115, 18-24. doi: 10.1007/BF01293576

Shimmen, T., and Tazawa, M. (1985). Mechanism of inhibition of cytoplasmic streaming by myrmicacin ( $\beta$ - Hydroxydecanoic acid) in Chara and Spirogyra. Protoplasma 127, 93-100. doi: 10.1007/BF01273705

Shimmen, T., and Yano, M. (1984). Active sliding movement of latex beads coated coated with skeletal muscle myosin on Chara actin bundles. Protoplasma 121, 132-137. doi: 10.1007/BF01279760

Shimmen, T., and Yano, M. (1986). Regulation of myosin sliding along Chara actin bundles by native skeletal muscle tropomyosin. Protoplasma 132, 129-136. doi: 10.1007/BF01276992
Shimmen, T., and Yokota, E. (1994). Physiological and biochemical aspects of cytoplasmic streaming. Int. Rev. Cytol. 155, 97-139. doi: 10.1016/S00747696(08)62097-5

Shimmen, T., and Yoshida, S. (1993). Analysis of temperture dependency of cytoplasmic streaming using tonoplast-free cells of Characeae. Protoplasma 176, 174-177. doi: 10.1007/BF01378954

Sibaoka, T., and Tabata, T. (1981). Electrotonic coupling between adjacent internodal cells of Chara braunii: transmission of action potentials beyond the node. Plant Cell Physiol. 22, 397-411.

Smith, F. A., and Walker, N. A. (1978). Entry of methylammonium and ammonium ions into Chara internodal cells. J. Exp. Bot. 29, 107-120. doi: 10.1093/jxb/29.1.107

Smith, F. A., and Walker, N. A. (1989). Transport of potassium in Chara australis: I. A symport with sodium. J. Membr. Biol. 108, 125-137. doi: 10.1007/BF01871024

Spanswick, R. M., and Costerton, J. (1967). Plasmodesmata in Nitella translucens: structure and electrical resistance. J. Cell Sci. 2, 451-464.

Tazawa, M. (1964). Studies on Nitella having artificial cell sap. I. Replacement of the cell sap with artificial solutions. Plant Cell Physiol. 5, 33-43.

Tazawa, M., Kikuyama, M., and Shimmen, T. (1976). Electric characteristics and cytoplasmic streaming of Characeae cells lacking tonoplast. Cell Struct. Funct. 1, 165-175. doi: $10.1247 / \mathrm{csf} .1 .165$

Tazawa, M., Kishimoto, U., and Kikuyama, M. (1974). Potassium, sodium and chloride in the protoplasm of Characeae. Plant Cell Physiol. 15, 103-110.

Tazawa, M., and Shimmen, T. (1982). Artificial control of cytoplasmic pH and its bearing on cytoplasmic streaming, electrogenesis and excitability of characeae cells. J. Plant Res. 95, 147-154. doi: 10.1007/BF02488581

Teakle, N. L., and Tyerman, S. D. (2010). Mechanisms of $\mathrm{Cl}^{-}$transport contributing to salt tolerance. Plant Cell Environ. 33, 566-589. doi: 10.1111/j.1365-3040.2009.02060.x

Tester, M., Beilby, M. J., and Shimmen, T. (1987). Electrical characteristics of the tonoplast of Chara corallina: a study using permeabilised cells. Plant Cell Physiol. 28, 1555-1568.

Timme, R. E., Bachvaroð, T. R., and Delwiche, C. H. F. (2012). Broad phylogenomic sampling and the sister lineage of land plants. PLOS ONE 7:e29696. doi: 10.1371/journal.pone.0029696

Tominaga, Y., Muto, S., Shimmen, T., and Tazawa, M. (1985). Calmodulin and $\mathrm{Ca}^{2+}$ - controlled cytoplasmic streaming in characean cells. Cell Struct. Funct. 10, 315-325. doi: 10.1247/csf.10.315

Tominaga, Y., and Tazawa, M. (1981). Reversible inhibition of cytoplasmic streaming by intracellular $\mathrm{Ca}^{2+}$ in tonoplast-free cells of Chara australis. Protoplasma 109, 103-111. doi: 10.1007/BF01287633

Tominaga, Y., Wayne, R., Tung, H. Y. L., and Tazawa, M. (1987). Phosphorylationdephosphorylation is involved in $\mathrm{Ca}^{2+}$-controlled cytoplasmic streaming of characean cells. Protoplasma 136, 161-169. doi: 10.1007/BF01276365

Trebacz, K., Fenson, D. S., Harris, A., and Zawadski, T. (1988). Transnodal transport of ${ }^{14} \mathrm{C}$ in Nitella flexilis III. Further studies on dissolved inorganic carbon movements in tandem cells. J. Exp. Bot. 39, 1561-1573. doi: $10.1093 / \mathrm{jxb} / 39.11 .1561$

Turnaev, I. I., Gunbin, K. V., and Afonnikov, D. A. (2015). Plant auxin biosynthesis did not originate in charophytes. Trends Plant Sci. 20, 463-465. doi: 10.1016/j.tplants.2015.06.004

Tyerman, S. D., and Findlay, G. P. (1989). Current-voltage curves of single $\mathrm{Cl}^{-}$ channels which coexist with two types of $\mathrm{K}^{+}$channel in the tonoplast of Chara corallina. J. Exp. Bot. 40, 105-117. doi: 10.1093/jxb/40.1.105

Tyerman, S. D., Terry, B. R., and Findlay, G. P. (1992). Multiple conductances in the large $\mathrm{K}^{+}$channel from Chara corallina shown by a transient analysis method. Biophys. J. 61, 736-749. doi: 10.1016/S0006-3495(92)81878-7

Ullrich, W. R., and Glasser, E. (1982). Sodium-phosphate cotransport in the green alga Ankistrodesmus braunii. Plant Sci. Lett. 27, 155-161. doi: 10.1016/03044211(82)90144-4

Walker, N. A. (1955). Microelectrode experiments on Nitella. Aust. J. Biol. Sci. 8, 476-489. doi: 10.1071/BI9550476

Walker, N. A. (1994). "Sodium-coupled symports in the plasma membrane of plant cells," in Proceedings of the Society for Experimental Biology Symposium XLVIII: Membrane Transport in Plants and Fungi: Molecular Mechanisms and Control, eds M. R. Blatt, R. A. Leigh, and D. Sanders (Cambridge: The company of Biologists), 179-192. 
Walker, N. A., Beilby, M. J., and Smith, F. A. (1979a). Amine uniport at the plasmalemma of charophyte cells: I. Current - voltage curves, saturation kinetics, and effects of unstirred layers. J. Membr. Biol. 49, 21-55. doi: 10.1007/BF01871038

Walker, N. A., and Bostrom, T. E. (1973). "Intercellular movement of chloride in Chara - a test of models for chloride influx," in Ion Transport in Plants, ed. W. P. Anderson (London: Academic Press), 447-461.

Walker, N. A., Reid, R. J., and Smith, F. A. (1993). The uptake and metabolism of urea by Chara australis. IV. Symport with sodium - a slip model for the high and low affinity system. J. Membr. Biol. 136, 263-271. doi: 10.1007/BF00233665

Walker, N. A., Smith, F. A., and Beilby, M. J. (1979b). Amine uniport at the plasmalemma of charophyte cells. II. Ratio of matter to charge transported and permeability of free base. J. Membr. Biol. 49, 283-296. doi: 10.1007/BF018 71123

Wang, C., Liu, Y., Li, S.-S., and Han, G.-Z. (2014). Origin of plant auxin biosynthesis in charophyte algae. Trends Plant Sci. 19, 741-743. doi: 10.1016/j.tplants.2014.10.004

Wickett, N. J., Mirarab, S., Nguyen, N., Warnow, T., Carpenter, E., Matasci, N., et al. (2014). Phylotranscriptomic analysis of the origin and early diversification of land plants. Proc. Natl. Acad. Sci. U.S.A. 111, E4859-E4868. doi: 10.1073/pnas.1323926111

Williamson, R. E. (1972). A light-microscope study of the action of cytochalasin B on the cells and isolated cytoplasm of the characeae. J. Cell Sci. 10, 811-819.

Williamson, R. E. (1974). Actin in the alga Chara corallina. Nature (Lond.) 248, 801-802. doi: $10.1038 / 248801 \mathrm{a} 0$

Williamson, R. E. (1975). Cytoplasmic streaming in Chara: a cell model activated by ATP and inhibited by cytochalasin B. J. Cell Sci. 17, 655-668.
Williamson, R. E., and Ashley, C. C. (1982). Free $\mathrm{Ca}^{2+}$ and cytoplasmic streaming in the alga Chara. Nature 296, 647-651. doi: 10.1038/296 $647 \mathrm{a} 0$

Williamson, R. E., and Toh, B. (1979). "Motile models of plant cells and the immunofluorescence localisation of actin in a motile Chara cell model," in Cell Motility: Molecules and Organisation, eds H. I. S. Hatano and H. Sato (Tokyo: University of Tokyo Press).

Wodniok, S., Brinkmann, H., Glockner, G., Heidel, A. J., Philippe, H., Melkonian, M., et al. (2011). Origin of land plants: do conjugating green algae 1776 hold the key? BMC Evol. Biol. 11:104. doi: 10.1186/1471-2148-11-104

Zawadski, T., and Fenson, D. S. (1986a). Transnodal transport of ${ }^{14} \mathrm{C}$ in Nitella flexilis: I Tandem cells without applied pressure gradients. J. Exp. Bot. 37, 1341-1352. doi: 10.1093/jxb/37.9.1341

Zawadski, T., and Fenson, D. S. (1986b). Transnodal transport of ${ }^{14} \mathrm{C}$ in Nitella flexilis II. Tandem cells with applied pressure gradients. J. Exp. Bot. 37, 13531363. doi: $10.1093 / \mathrm{jxb} / 37.9 .1353$

Conflict of Interest Statement: The author declares that the research was conducted in the absence of any commercial or financial relationships that could be construed as a potential conflict of interest.

Copyright $\odot 2016$ Beilby. This is an open-access article distributed under the terms of the Creative Commons Attribution License (CC BY). The use, distribution or reproduction in other forums is permitted, provided the original author(s) or licensor are credited and that the original publication in this journal is cited, in accordance with accepted academic practice. No use, distribution or reproduction is permitted which does not comply with these terms. 